\title{
Ecological and Economic Context of Managing Enterprises That Are Particularly Harmful to the Environment and the Well-Being of Society
}

\author{
Aneta Włodarczyk * and Agata Mesjasz-Lech
}

Citation: Włodarczyk, A.;

Mesjasz-Lech, A. Ecological and

Economic Context of Managing

Enterprises That Are Particularly

Harmful to the Environment and the

Well-Being of Society. Energies 2021,

14, 2884. https://doi.org/10.3390/

en14102884

Academic Editor: Brian D. Fath

Received: 19 April 2021

Accepted: 14 May 2021

Published: 17 May 2021

Publisher's Note: MDPI stays neutral with regard to jurisdictional claims in published maps and institutional affiliations.

Copyright: (c) 2021 by the authors. Licensee MDPI, Basel, Switzerland. This article is an open access article distributed under the terms and conditions of the Creative Commons Attribution (CC BY) license (https:/ / creativecommons.org/licenses/by/ $4.0 /)$.
Faculty of Management, Czestochowa University of Technology, Dabrowskiego 69, 42-201 Czestochowa, Poland; agata.mesjasz-lech@wz.pcz.pl

* Correspondence: aneta.wlodarczyk@wz.pcz.pl

\begin{abstract}
The ecological and economic context determine the management goals of a modern enterprise, which are in line with the growing concern about the well-being of society caused by the effects of enterprises' activities that are particularly harmful to the environment. This increases the need to search for new tools that will have the capacity to generate information supporting the decision-making process in the area of enterprise management in terms of ecological, economic, and social goals. For these reasons, synthetic measures of development were constructed on the basis of the set of diagnostic variables describing various aspects of sustainable development in the case. Based on the environmental synthetic indicators, it has been possible to point out the Polish voivodeships, in which enterprises that are particularly harmful to the environment were able to reduce the emissions of dust and gaseous pollutants in the 2005-2019 period. These changes were often accompanied by an increase in the production of energy from renewable sources and increasing the supply of plants with devices to contain gaseous and dust pollutants. Moreover, the comparison of positioning the voivodeships in the rankings according to social, economic, and environmental synthetic measures shows that the reduction of the negative impact of energy-intensive enterprises on the environment has been associated with higher the position of the voivodeship in the ranking connected with the health of its inhabitants. It has been also seen that the largest pool of funds was allocated to the voivodeships that need them the most, as these voivodeships were low in the ranking with respect to the degree of the reduction of dust and gaseous emissions by enterprises that are particularly harmful to the environment. The results for regression analysis indicated at the existence of the inter-temporal relationships between the well-being of society and the environmentaleconomic effects of enterprises' activities. It was noticed that increasing the possibilities of financing investments in low-emission development of the region, including the modernization of enterprises in terms of decreasing dust and gaseous pollutant emissions and reducing their energy consumption, has a significant impact on the improvement of well-being of society with a one-year lag. In contrast to other studies that mainly refer to the environmental and economic effects of managing enterprises that are particularly harmful to the environment, this paper focuses on the social aspect of the change in the health of the population connected with the emissions of pollutants. A novel approach based on the set of three multi-criteria synthetic measures is proposed to assess the environmental, economic, and social activities of enterprises in individual voivodeships in Poland in the long 2005-2019 period.
\end{abstract}

Keywords: enterprises management; enterprises of particularly harmful to air quality; environmental activities; sustainable development; well-being of society; synthetic development measures

\section{Introduction}

Environmental protection, understood as all activities intended to ensure the proper use and recovery of resources and environmental components, is increasingly present in the economic reality. The natural environment has always been an important and conditioning element of the business environment. For this reason, economic entities seek to protect the 
natural environment and undertake various activities to realize this goal. The dynamic development of the management methods and concepts has led to the implementation of environmental activities in the functioning of organizations and to the development of tools for the realization of these activities. The pro-environmental behaviors of business entities are the direct result of recognizing legal regulations and the needs of environmentally aware customers. Unfortunately, among the businesses that are particularly harmful to the environment, reactive behaviors still outstrip the proactive ones. Activities undertaken by these businesses are intended to meet the requirements of the legal and administrative regulations at both the state and regional level [1]. The basic legal act determining the directions of pro-ecological activities for Polish enterprises is the Circular Economy Action Plan, which was adopted by the European Commission in 2020. The plan presents a way of developing a climate-neutral and competitive economy by changing the way we produce and consume goods. The state-level regulations were determined in the following: The Partnership Agreement, adopted by the European Commission on 23 May 2014, as the basis for the development of the Infrastructure and Environment Operational Program 2014-2020, which was adopted by the European Commission on 18 December 2014, National Development Strategy 2020, The medium-term strategy, Energy Security and Environment-perspective until 2020, the Concept of the National Spatial Planning 2030, National Health Program for the years 2007-2015, Transport Development Strategy until 2020 with a perspective until 2030, Polish Energy Policy until 2030, National Renewable Energy Plan 2010, Polish Energy Efficiency Action Plan 2014, Polish Policy for the Oil Industry, Policy for the Natural Gas Industry, Polish Hard Coal Mining Strategy for the years 2007-2015, the Strategy of the Innovation and Effectiveness of the Economy, and the National Waste Management Plan 2014. On the level of voivodeships, the trends in the activities were determined in the following documents: The Regional Operational Program of the Voivodeship, the Strategy for the Voivodeship Development, the results of the air quality assessment and the classification of zones in the voivodeship, Air Protection Program, the Spatial Development Plan for the Voivodeship, Program for the Development of Transport Infrastructure of the Voivodeship, Environmental Protection Plan for the Voivodeship, Waste Management Plan for the Voivodeship.

The environment is the common value of societies regardless of ideology [2]. Implementing a proactive environmental strategy brings competitive advantage [3]. There is a broad spectrum of proactive environmental management practices carried out by businesses, from purely reactive activities aimed at meeting the minimum regulative requirements to innovative projects for developing new waste prevention technologies. In fact, the value of proactive environmental management is increasingly recognized by decisionmakers. However, this does not mean that the proactive behaviors are perceived as the fundamental element of management in the context of environmental protection. There is also a shortage of practical instructions on the implementation of such behaviors at a business entity level [4]. One should also remember that the ecological balance of business entities is interrelated with the energy balance. Proper environmental and energy management of enterprises determines their success on the market, which is primarily due to the growing ecological awareness of customers who more and more often choose products that do not generate environmental impact at any stage of the life cycle [5,6], which translates into a higher quality of life.

For this reason, the ecological and economic context should determine the management goals of a modern enterprise. As the role of the principles of sustainable development in the activities of enterprises is growing, thinking not only in economic but also in environmental and social terms must be the basis for building management strategies. For this reason, this paper investigates the relationship between the social effects and the economic and environmental effects related to the activities of the enterprises of significant nuisance to air quality in Poland over the 2005-2019 period. It has been focused on the necessity to quantify these three effects. Since the social, economic, and environmental effects are the pillars of sustainable development, they can be measured using the indicators of sustainable 
development. In this context, the economic effects include the amount of financial resources for pro-environmental activities. The resources come mainly from environmental funds, loans and credits, EU funds, air and climate protection fees. The environmental effects of plants that are particularly harmful to the environment can be connected primarily with the emission levels of all kinds of air pollutants. Social effects with reference to enterprises should be connected with their impact on the well-being of society, and particularly on the health of the population. The activity of enterprises that are particularly harmful to the environment is characterized by high emissions of air pollutants. Bad quality of air has a negative influence on the health of society, generating expenditure on treatment or costs of decreased productivity caused by sick leaves or connected with employees eligible for early retirement or pension.

Taking into account the need to develop the analysis of the mutual influence of all three pillars of sustainable development as the core element of the functioning of modern enterprises, the following research questions were asked:

1. Do synthetic measures of development designed on the basis of a set of diagnostic variables corresponding to sustainable development indicators have the capacity to generate information supporting the decision-making process in the area of enterprise management in terms of ecological, economic, and social goals?

2. Are there any positive trends in the achieved level of environmental, economic, and social effects connected with the activities of enterprises that are harmful to the environment in individual voivodeships in Poland in 2005-2019?

The present study contributes to the literature on the subject in three following respects. Firstly, synthetic measures of development were constructed to measure the environmental, economic, and social effects of enterprises that are particularly harmful to the environment on the basis of the set of diagnostic variables describing various aspects of sustainable development. Secondly, the usefulness of the set of synthetic variables in the diagnosis of economic, environmental, and social activities of enterprises in individual voivodeships was verified. A set of three multi-criteria synthetic measures was used to assess the impact of enterprises that are particularly harmful to the environment in Poland in the long 2005-2019 period, in which Poland, as an EU member, had access to funds for the creation of a low-emission economy, and it was obliged to adjust the emission factors to the EU standard. Thirdly, the previous analyses comparing the environmental and economic effects of managing enterprises that are particularly harmful to the environment were extended to include the extremely important social aspect of the change in the health of the population connected with the emissions of pollutants. It is important because the surveyed enterprises represent the sectors of the economy with the highest dust and gaseous emission indicators in Poland. The analyses carried out using synthetic measures of development help identify the relationships between various aspects of the activities of companies that are particularly harmful to the environment, which yields innovative knowledge about the ecological and economic context of enterprise management that is very useful from a practical point of view.

The remainder of the paper is organized as follows. A brief review of the relevant literature is provided in the next section. Section 3 describes the data and variables used, as well as provides the description of the applied methodology. Section 4 presents the major empirical results and includes the discussion of the findings. Section 5 contains some concluding remarks and indicates the aspects of enterprise management in the environmental-economic and social dimensions during the period of the COVID-19 pandemic.

\section{Literature Review}

Growth in the production and consumption of goods leads to the increased environmental pollution, which means that both the waste and all kinds of air, soil, and water pollution are becoming problems. The majority of these problems are generated at the level of the energy management of enterprises. Environmental pollution deteriorates the quality of life. To prevent the degradation, enterprises implement in their activities the principles 
of sustainable development, which connect the economic, social, and ecological aspects. In an economy that affects the ecosystem negatively, customers increasingly choose to behave in a socially responsible way with regard to the environment. This leads to socially responsible consumption reflected mainly in saving energy, buying eco-friendly products, and sorting and recycling waste [7]. The subject literature emphasizes the conflict between the goals of the enterprise resulting from the realization of the basic principles of the concept of corporate social responsibility and profit maximization [8]. Enterprises put their focus primarily on their economic results [9], thus neglecting other aspects connected with their functioning, such as the social sphere [10]. However, treating profit maximization as the basic determinant of efficient operation is debatable. In the present-day economy, knowledge is an important factor determining competitive advantage, and the company's goal is to transform the intellectual capital into economic value [11,12]. For this reason, modern managers should have the ability to find a sustainable balance between the company's profits and other results and resources. However, ecological responsibility goes hand in hand not only with economic responsibility but also with social responsibility. Research on activities connected with the ecological responsibility of enterprises shows that the majority of enterprises define such activities as the ones that take into consideration the common good of the enterprise, the local society, and the environment [13].

Pro-environmental activities are also realized in the framework of the European Union. A big portion of the pollution generated by the member states can also be seen as a chance to address the shortages of resources and energy, increase the diversification of energy and material sources, and improve the safety of the supply of energy and other resources through increasing the dependence on import [14]. Uncertainty concerning the climate and energy policy reduces social welfare. The reason for this is that the higher degree of uncertainty of the climate and energy policy increases the uncertainty of the return on capital, which means that entities acting rationally postpone their investments [15]. Moreover, considering the fact that fossil fuels are the primary source of energy in many countries, the costs associated with producing energy from these sources are shifted onto customers, households, and businesses. The shift of costs causes the prices of goods to rise, which has a negative effect on the welfare of society [16]. An indirect consequence of the decrease in social welfare is the deterioration of health and lowering the age of social life $[17,18]$. That raises the question of whether the purpose of all kinds of instruments aimed at contributing to pro-environmental behavior of enterprises is to maximize their profits, maximize social welfare, or minimize the level of carbon dioxide emissions [19].

The majority of research on the impact of ecological and economic factors on the welfare of society focuses on analyses concerning the limits of economic growth while maintaining sustainable social welfare. Research of this kind is realized at the level of state [20] or sectors [21,22]. There are very few company-level analyses. Lundgren and Zhou [23], using the data envelopment analysis (DEA) technique and the panel vector auto-regression (VAR) methodology, analyzed the interactions between the productivity, energy efficiency, and environmental effectiveness of enterprises. They highlighted the role of investments for the reduction of environmental impact, which indirectly results in the increased competitiveness of enterprises and the effective use of energy. Alipour et al. [24] analyzed the relationship between the environmental disclosure quality and firm performance. Using static and dynamic panel data analysis, they showed a positive relationship between the variables. The relationship between direct foreign investments and the intensity of carbon dioxide emission was analyzed by Shao [25], using the dynamic model of panel data. The results showed that direct foreign investments have a significant influence on the intensity of carbon dioxide emission. When other factors were taken into account, including fossil fuel share, industrial intensity, urbanization, and the openness of trade, the impact of investments on carbon intensity was still statistically significant. In their research, Kapuria and Singh [26] demonstrated a dependence between direct foreign investments and the growth and sustainability dimension in the context of environmental, economic, social, and governance of sustainable development. Static and dynamic panel 
estimation methods were used in the article. Economic, environmental, and social effects are usually comprised of a few variables, which is why they are often measured using synthetic methods [27-30]. These measures can often relate to environmental and economic performance [31-35]. However, there is a lack of research on the impact of economic and environmental factors on social factors, especially in the area of population health and life expectancy.

Taking into account the environmental and economic context in the management of the enterprise presupposes the development of programs and the implementation of activities for the reduction of the emissions of pollutants in order to achieve compliance with the environmental regulations in the most economical way [36]. It also involves finding additional sources of financing investments in modern production technologies. Three important dimensions of the implementation of measures for the reduction of air emissions in the company are highlighted: carbon governance, which refers to the organizational capacity to deal with the risk of emissions and to identify opportunities to mitigate the company's environmental impact; reduction of pollutant emissions, which depends on the activity of companies in this respect: developing own reduction policy and a system for monitoring emissions generated by companies; improving production processes by finding and implementing new technological solutions; ensuring competitiveness of companies by creating innovative organizational solutions and developing scientific and research cooperation in the field of the creation of new low-emission technologies; and stakeholder involvement in voluntary programs to reduce the company's negative impact on the environment [37]. It is expected that taking the environmental and economic context into account in the long-term management of the company should improve the company's indicators of emissions, which is the subject of many studies [38-40], which include studies using panel models. The panel regression models for financial indicator (return on equity $(R O E)$, return on assets $(R O A)$, return on investment $(R O I)$, return on sales $(R O S)$, or Tobin's $Q)$ and energy intensity of firms were estimated for Chinese firms representing six highenergy-consuming industries in the 2010-2014 period. The results show that low energy consumption translates into better financial results of Chinese companies [41]. The fixed effect and random effect panel models were estimated to evaluate the relationship between the adoption of renewable energy and financial indicators ( $R O A, R O E$, and Tobin's $\mathrm{Q}$ ) for 66 electric utilities over the 2005-2014 period. The results indicate a negative relationship between the increase in renewable energy production and the company's short- and long-term financial result [42]. Other studies also focused on the relationship between financial performance indicators ( $R O A, R O E$, Tobin's $Q)$ and environmental performance scores. Panel regression models were estimated based on a large, international sample of companies that were highly intense regarding the use of fossil fuels in the 2002-2013 period. The study shows that companies from the fuel industry have well-developed environmental policies and environmental risk management systems compared to companies from other sectors, but their pro-environmental activities are less effective [43]. In the studies described above, the environmental aspects and financial effects were measured using single variables. It is also worth paying attention to a study in which this type of dependence was measured using an aggregate pollutant emission index, which was standardized due to the impact of each pollutant on human health. Using a sample of Czech firms in the 2004-2008 period, a panel linear regression model was estimated for the financial indicator $(R O A, R O E)$ and normalized environmental indicator. It was found that the increase in the firms' emissions depletes profitability in the 2-year delay period but improves it in the 1-year delay period [44]. In the case of Polish energy companies, the Spearman rank correlation coefficient was used in order to evaluate the relationship between environmental indicators (carbon intensity and the ratio of carbon dioxide emissions over the allowances) and financial indicators (ROA, ROI, ROS), which were estimated for Polish energy companies in the 2013-2017 period. It was stressed that while making decisions on investments into low-carbon modernization, Polish energy companies more and more often take economic factors into consideration. These factors include financial 
results, electricity cost for final customers, and chances of obtaining additional EU funds for carrying out the investments [45].

\section{Research Methodology and Data Description}

\subsection{Data and Variables}

The analysis covered plants of significant nuisance to air quality, which, according to the definition of the Central Statistical Office, include all organizational units (plants) with the highest national emissions of air pollutants. This group of entities includes production companies in the energy and industrial sector, which basically determines the scale and structure of pollutant emissions. The population of plants of significant nuisance to air quality in Poland grew from 1695 in 2005 to 1878 in 2019 [46]. As the Polish voivodeships are strongly diversified in terms of their economic structure, the availability of energy carriers, and the concentration of enterprises that are particularly harmful to the environment, the synthetic measures of development proposed in the article refer to groups of enterprises operating in individual voivodeships.

The indicators of sustainable development of Poland, which indicate the need for sustainable protection of natural, social, and economic capital, were assumed as variables [47]. The indexes connected with the environmental and economic capital take into account the ecological and economic context of the study; the social capital indicators represent the well-being of society. Hence, to measure the ecological and economic context, the following set of indicators was proposed, and the direction of their impact on a complex phenomenon was determined:

1. Environmental indicators:

- Dust emission ( $\mathrm{t} / \mathrm{plant}$; destimulant)

- Sulfur dioxide emission $\left(\mathrm{SO}_{2}\right)(\mathrm{t} /$ plant; destimulant)

- Nitrogen oxides emission $\left(N O_{x}\right)(t /$ plant; destimulant $)$

- Carbon oxide emission (CO) ( $\mathrm{t} /$ plant; destimulant)

- Carbon dioxide emission $\left(\mathrm{CO}_{2}\right)$ (t/plant; destimulant)

- Plants equipped with appliances for the reduction of dust pollutants in relation to plants emitting dust pollutants (\%; stimulant)

- Plants equipped with appliances for the reduction of gaseous pollutants in relation to plants emitting gaseous pollutants (\%; stimulant)

- The level of dust pollutants reduction in the appliances of the plants of significant nuisance to air quality (\%; stimulant)

- The level of gaseous pollutants reduction in the appliances of the analyzed plants (\%; stimulant)

- Share of renewable energy in the total production of energy (\%; stimulant)

- Total electricity consumption in the industry sector and the energy sector per unit of gross value added (GWh/million PLN; destimulant)

2. Economic indicators:

- Outlays on fixed assets with new combustion technologies (PLN per capita; stimulant)

- Outlays on fixed assets connected with the reduction of dust pollutants (PLN per capita; stimulant)

- Outlays on fixed assets connected with the reduction of gaseous pollutants (PLN per capita; stimulant)

- Outlays on fixed assets for saving energy (PLN per capita; stimulant)

- Financing fixed assets for environmental protection from domestic credits and loans (PLN per capita; stimulus)

- Financing fixed assets for environmental protection from ecological funds (PLN per capita; stimulus)

- Financing environmental protection from foreign funds (PLN per capita; stimulus) 
- Financial inflows from air and climate protection fees (including penalty fees for exceeding the permissible emissions of air pollutants) (PLN per capita; destimulant).

In the analysis of the effects of the environmentally negative activities of enterprises on human health, more and more attention is paid to years of life lost, premature deaths, working days lost, or asthma attacks [48]. For this reason, a synthetic indicator of development referring to the well-being of society in terms of the health condition of the inhabitants of a voivodeship was also proposed to indicate the social effects of the functioning of enterprises in terms of social welfare. The indicator was constructed using the following diagnostic variables:

- Deaths of the inhabitants of the voivodeship caused by the respiratory system diseases (pneumonia, bronchitis, emphysema, and asthma) (number of deaths $/ 100,000$ inhabitants; destimulant)

- Deaths caused by malignant neoplasms of the respiratory system (cancers of the trachea, bronchi, and lungs) (number of deaths/100,000 inhabitants; destimulant)

- Deaths caused by cardiovascular diseases (deaths/100,000 inhabitants; destimulant)

- Life expectancy for men at the age of 45 (years; stimulant)

- $\quad$ Life expectancy for women at the age of 45 (years; stimulant)

- Life expectancy for men at the age of 15 (years; stimulant)

- Life expectancy for women at the age of 15 (years; stimulant).

Data required for the estimation of the diagnostic variables for individual Polish voivodships in the years 2005-2019 come from the databases of the Central Statistical Office: Local Data Bank [49], Economic aspects of environmental protection 2020 [50], and Environmental protection 2006-2020 [51].

\subsection{The Method of the Synthetic Indicator of Development and the Econometric Panel Model}

The ranking of the voivodeships was carried out using the development pattern method, which is based on a synthetic measure designed for differentiating objects in a multidimensional analysis and ranking them [52]. For this purpose, the following applied:

1. All diagnostic variables used for the analysis were classified into one of the three categories of variables: stimulant, destimulant, or nominant. Nominants measured on a ratio scale should be transformed into stimulants using the following transformation:

$$
x_{i j}=\frac{\min \left\{n^{\prime} m_{j} ; x_{i j}^{N}\right\}}{\max \left\{n o m_{j} ; x_{i j}^{N}\right\}},
$$

where $x_{i j}^{N}$-the value of the $j$-th nominant for the $i$-th object, nom - $_{j}$ the nominal value of the $j$-th variable.

2. Next, the value of each diagnostic variable measured at least on the interval scale was standardized using the following formula:

$$
z_{i j}=\frac{x_{i j}-\bar{x}_{j}}{s_{j}},(\mathrm{i}=1,2, \ldots, n ; \mathrm{j}=1,2, \ldots, \mathrm{m})
$$

where $x_{i j}$-the value of the $j$-th diagnostic feature $X_{j}$ describing the $i$-th object $O_{i}, \bar{x}_{j}$-the arithmetic mean of the $X_{j}$ diagnostic variable, $s_{j}$-standard deviation of the diagnostic variable $X_{j}, z_{i j}$-standard values of this variable for the $i$-th object, $m$ - the number of diagnostic variables, $n$-the number of objects. The $Z_{j}$ variable with the mean equal to zero and a singular standard deviation is measured already on the interval scale, which means that the performed transformation of the diagnostic variables brought their orders of magnitude to the state of comparability [53]. 
3. A reference object $\left(O_{w}\right)$ and an anti-reference object $\left(O_{a}\right)$. They are respectively represented geometrically by the points $z_{w}=\left(z_{w j}\right)_{j \in\{1,2, \ldots, m\}}$ and $z_{a}=\left(z_{a j}\right)_{j \in\{1,2, \ldots, m\}}$ with the following coordinates:

$$
\begin{aligned}
& z_{w j}= \begin{cases}\max _{i} z_{i j} & \text { dla stymulant } \\
\min _{i} z_{i j} & \text { dla destymulant }\end{cases} \\
& z_{a j}= \begin{cases}\min _{i} z_{i j} & \text { dla stymulant } \\
\max _{i} z_{i j} & \text { dla destymulant }\end{cases}
\end{aligned}
$$

4. The synthetic development measure $\left(m_{i}\right)$ for the $i$-th object was determined according to the relationships in Equations (5) and (6):

$$
\begin{gathered}
m_{i}=1-\frac{d\left(z_{i j}, z_{w j}\right)}{d\left(z_{a j}, z_{w j}\right)},(\mathrm{i}=1,2, \ldots, n) \\
d\left(z_{i j}, z_{w j}\right)=\sqrt{\sum_{j=1}^{m}\left(z_{i j}-z_{w j}\right)^{2}},(\mathrm{i}=1,2, \ldots, n)
\end{gathered}
$$

where $d\left(z_{i j}, z_{w j}\right)$-the distance of the $i$-th object from the model object measured using the Euclidean metric, $d\left(z_{a j}, z_{w j}\right)$-the distance between the development reference object and the anti-reference object.

Values of the measures $m_{i}$ are in the range $[0 ; 1]$.

5. The objects were ordered in descending order in relation to the value of the synthetic measure, the voivodeship with the highest level of the synthetic measure value was given rank 1, and the voivodeship with the lowest level of the value was given rank 16.

In order to verify the assumption about the stability of environmental, economic, and social results achieved by enterprises in individual Polish voivodeships, the existence of a similarity of the orderings for the discussed effects of the functioning of enterprises was checked. For this purpose, the value of the Spearman rank correlation coefficient was calculated:

$$
r_{S}=1-\frac{6 \cdot \sum d_{i}^{2}}{n \cdot\left(n^{2}-1\right)}
$$

where $d_{i}$-the difference between the positions in the rankings for a given effect of the functioning of enterprises, $n$-the size of the statistical sample.

In order to identify the relationship between the environmental, economic, and social effects of activities of analyzed enterprises, the following regression model was also estimated for the 2005-2019 period:

$$
S I_{i t}=\alpha_{0}+\rho_{1} S I_{i, t-1}+\sum_{k=0}^{j} \beta_{k} E I_{i, t-k}+\sum_{k=0}^{j} \gamma_{k} G I_{i, t-k}+\sum_{k=0}^{j} \varphi_{k} G V A_{i, t-k}+\alpha_{1} D_{2013, t}+\alpha_{2} D_{E i, t-1}+u_{i t}
$$

where $S I_{i t}$-synthetic measure of development describing the well-being of society in the $i$-th voivodeship $(i=1,2, \ldots, 16)$ in the year $t(t=1,2, \ldots, 15) ; E I_{i t}$-synthetic measure of development describing the environmental effects of the activity of enterprises especially harmful to the environment in an $i$-th voivodeship in the period $t, G I_{i t}$-synthetic measure of development describing the economic effects of the activity of enterprises in the $i$-th voivodeship in the period $t, \alpha_{i}(i=0,1,2), \beta_{k}, \gamma_{k}, \varphi_{k}(k=0,1, \ldots, j)$-parameters, $\rho_{1}$ parameter describing the autoregressive dependence of the value of the synthetic measure of development $S I$ as the improvement or worsening of human health adjustment process is relatively slow; $u_{i t}$-error term, which consists of unobserved time and individual specific effects, and residuals $v_{i t}$ that are assumed to be independently distributed across 
individuals with a zero mean (arbitrary forms of heteroscedasticity across units and time are possible) [54].

The EI and GI synthetic indicators are lagged in the panel regression (8), since it may take time to see the results of both environmental and economic activities that have been implemented by enterprises responsible for air pollution. A similar assumption was made in previous studies (e.g., [44,55]). The order of the lag of the variables was chosen using the criterion of the significance of the model parameters and the results of diagnostic tests.

Additional control variables were also included in the modeling. Considering the changes in the climate and energy policy described earlier, a dummy variable $D_{2013}$ was introduced. The variable takes the value 1 in 2013 and the value 0 in the other years. In order to describe the effect of the diversification of Polish voivodeships in terms of industrialization, which affects the well-being of society and is connected with energy consumption and the level of emissions of pollutants into the air by plants that are particularly harmful to the environment, the GVA control variable was introduced. $G V A_{i t}$ represents the gross value added of the industrial and energy sector (expressed in thousands PLN in constant prices from 2005 per capita) in the $i$-th voivodeship in the period $t$. Industrialized Polish voivodeships with a strong concentration of industrial and energy plants showed high values of the GVA variable. Additionally, panel models with the dummy variable $D_{E}$ taking the value of 1 were estimated, if the number of plants that are particularly harmful to the environment per 100,000 inhabitants in the $i$-th voivodeship was high (exceeded the third quartile in the period $t-1$ ).

The dynamic generalized method of moments $(G M M)$ estimators with one-step or two-step robust standard errors are applied to estimate the panel model (8). An in-depth discussion of the properties of the estimator can be found in the previous research $[54,56,57]$. The validity of the GMM estimation is followed by a set of diagnostic tests. The lags included in the panel regression need to be examined for serial correlation, as the first differencing residuals ought to be correlated $(A R(1)$ test) and there should not be second-order serial correlation in errors (AR(2) test) [56]. Additionally, the validity of the instruments is checked using the Sargan test in order to detect the overidentifying restrictions problem [54].

\section{Empirical Results and Discussion}

\subsection{Analysis of the Synthetic Development Measures for the Environmental, Economic, and Social Dimension}

The synthetic development indicators were estimated for the years 2005, 2013, and 2019 using Formulas (1)-(6) according to the availability of data. Polish voivodeships were compared in terms of the level of achieved environmental effects (connected with the emissions of dust and gaseous pollutants by plants that are particularly harmful to the environment, and the consumption of energy by industrial and power plants), economic (connected with outlays on fixed assets for the protection of air and climate), and social (population health) of sustainable development in 2005, 2013, and 2019. The years 2005 and 2013 are important periods in the functioning of the European Emissions Trading System (EU ETS), which included energy and industrial installations that significantly threaten the cleanliness of air. The goal of the EU ETS was to bring effects in the form of investments helping reduce the emission of greenhouse gases and indirectly also other pollutants released into the air. Additionally, in 2013, the European Commission reviewed the "Strategy on air pollution" adopted in 2005, which contributed to the development of new regulations on the emission of certain air pollutants from medium combustion sources (COM (2013) 919) and the reduction of domestic emissions of certain types of air pollutants (COM (2013) 920) (National Program for Environmental Protection until 2020, Ministry of Environmental Protection, Department of Climate Protection, Warsaw 2015).

Figure 1 shows that in the analyzed years, the lowest values of the environmental development measure are connected with the Łódzkie voivodeship (0.2807-2019). The values are low due to the very high emission rates of sulfur dioxide, nitrogen oxides, carbon monoxide, and carbon dioxide, which are accompanied by combustion processes of conventional fuels in plants especially harmful to the environment. Compared to the 
previous years, in 2019, the value of the environmental indicator decreased for the Opolskie voivodeship (from 0.4729-2013 to 0.3568) and Świętokrzyskie voivodeship (from 0.48892005 to 0.3402 ). This was mainly due to an increase in the energy consumption by the industry and energy sectors, which remained at a very high level in these voivodeships$0.3007 \mathrm{GWh} /$ million PLN (Opolskie voivodeship) and $0.3092 \mathrm{GWh} /$ million PLN (Świętokrzyskie voivodeship), compared to the average ( $0.1970 \mathrm{GWh} / \mathrm{PLN}$ million) for Polish voivodeships in 2019. It is worth noting that in 2005, the average level of energy consumption in the industry and energy sectors was $0.3364 \mathrm{GWh} /$ million PLN, with the two worst voivodeships recording a drop in the value of this indicator in 2019 compared to 2005: from 0.5548 to $0.2587 \mathrm{GWh} /$ million PLN (Ślaskie voivodeship) and from 0.4484 to $0.2524 \mathrm{GWh} /$ million PLN (Lubelskie voivodeship). These changes were accompanied by an increase in the production of energy from renewable sources. In half of the Polish voivodeships, the share of renewable energy in the total electricity production was only $3.5 \%$ in 2005 and $10.9 \%$ in 2013 , but it grew to $22.4 \%$ in 2019 . The following voivodeships took advantage of the environmental conditions and developed the production of renewable energy, which significantly changed the structure of electricity production in 2005-2019: Podlaskie (increase in the share of energy from renewable sources in total production from $1.3 \%$ to $75.2 \%$ ), Pomorskie (an increase from $10.7 \%$ to $51.9 \%$ ), WarmińskoMazurskie (an increase from $16.8 \%$ to $85.7 \%$ ), and Zachodniopomorskie (an increase from $5.5 \%$ to $55.6 \%)$.

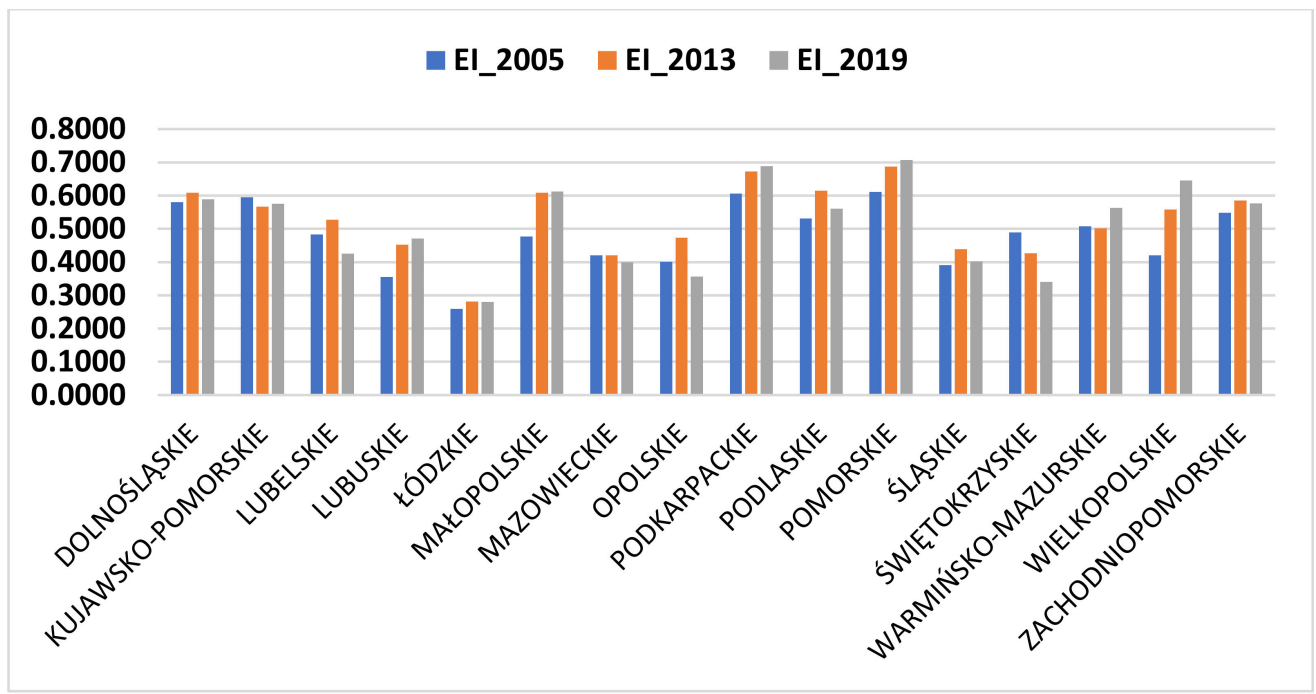

Figure 1. The values of the synthetic development measures relating to the environmental effects for individual voivodeships in Poland in 2005, 2013, and 2019. Source: Own elaboration based on the data of the Central Statistical Office.

The best environmental effects in the long term are observed in the Podkarpackie and Pomorskie voivodeships, for which the environmental order indicator was 0.6058 and 0.6111 in 2005, 0.6724 and 0.6870 in 2013, and 0.6891 and 0.7066 in 2019. In these voivodeships, the emission rates of dust and gaseous pollutants $\left(\mathrm{SO}_{2}, \mathrm{NO}_{x}, \mathrm{CO}, \mathrm{CO}_{2}\right)$ generated by enterprises that are particularly harmful to the environment were relatively low, and the degree of their reduction in the cleaning devices of the surveyed enterprises was high. In addition, in the years 2005-2019 in the Pomorskie and Podkarpackie voivodeships, the energy consumption of industry and energy showed a downward trend, and the share of renewable energy in the production of electricity was on the rise. It is also worth emphasizing the significant increase in the value of the environmental development measure for the Wielkopolskie voivodeship in 2019 (0.6458) compared to 2005 (0.4206). It was possible thanks to a significant reduction in the emissions of dust and gaseous pollutants, such as sulfur dioxide, nitrogen oxides, and carbon dioxide, from plants that are particu- 
larly harmful to the environment, and a simultaneous increase in the level of prevented gaseous emissions.

The most important goal of the activities in the field of air protection is to reduce air pollutant emissions far enough to be able to improve air quality and comply with legal standards. For this reason, changes in the level of dust and gaseous pollutant emissions generated by plants that are particularly harmful to the environment in individual voivodeships were examined.

The analysis of the descriptive statistics presented in Table 1 shows that the upper limit of the typical range of variability $(M e+Q)$ of the emission of all pollutants released into the air by plants particularly harmful to the environment decreased in 2019 compared to 2013, and in 2013 compared to 2005. The change was most noticeable in the case of dust and industrial gas emissions $\left(\mathrm{SO}_{2}\right.$ and $\left.\mathrm{NOx}\right)$, as the upper emission threshold in 2019 compared to 2005 decreased respectively by $79.2 \%$, 82.9\%, and $53.4 \%$. In 2019 , dust and $\mathrm{SO}_{2}$ emissions in each voivodeship were below the upper limit of the typical variability range from 2005, and in the case of $\mathrm{NO}_{x}$, the level was exceeded only in one voivodeship. This indicates a significant reduction of these three types of air pollutants generated by industrial plants in individual voivodeships in 2005, 2013, and 2019. It can be connected with the legislative changes introduced at the EU level and national regulations concerning the tightening of industrial pollutant emission standards in the analyzed years. The emissions of carbon monoxides and carbon dioxide also decreased in 2019 compared to 2013 or 2005 , but the number of voivodeships in which the upper emission variability level was exceeded indicates the need to continue the modernization of these plants in terms of their capability to reduce $\mathrm{CO}_{2}$ and $\mathrm{CO}$ emissions.

Table 1. Descriptive statistics for the emission of dust and gaseous pollutants by plants particularly harmful to the environment (in tons per company).

\begin{tabular}{|c|c|c|c|c|c|c|c|}
\hline Variable & Mean & Median & $Q 1$ & $Q 3$ & $M e-Q$ & $M e+Q$ & $K / K_{1}$ \\
\hline Dust emission 2005 & 62.88 & 65.19 & 46.13 & 78.71 & 48.90 & 81.48 & 2 \\
\hline Dust emission 2013 & 26.58 & 28.04 & 21.67 & 30.36 & 23.70 & 32.38 & $2 / 0$ \\
\hline Dust emission 2019 & 13.85 & 13.78 & 10.48 & 16.85 & 10.60 & 16.96 & $4 / 0$ \\
\hline $\mathrm{SO}_{2}$ emission 2005 & 462.22 & 327.86 & 151.11 & 455.51 & 175.66 & 480.06 & 4 \\
\hline $\mathrm{SO}_{2}$ emission 2013 & 210.98 & 165.78 & 111.24 & 245.46 & 98.67 & 232.89 & $5 / 2$ \\
\hline $\mathrm{SO}_{2}$ emission 2019 & 90.19 & 61.87 & 49.94 & 89.92 & 41.88 & 81.86 & $5 / 0$ \\
\hline $\mathrm{NO}_{\mathrm{x}}$ emission 2005 & 192.38 & 159.48 & 90.48 & 244.25 & 82.59 & 236.36 & 4 \\
\hline $\mathrm{NO}_{\mathrm{x}}$ emission 2013 & 158.01 & 152.15 & 77.62 & 203.03 & 89.45 & 214.86 & $3 / 2$ \\
\hline $\mathrm{NO}_{\mathrm{x}}$ emission 2019 & 97.18 & 78.41 & 55.71 & 119.36 & 46.59 & 110.24 & $4 / 1$ \\
\hline CO emission 2005 & 170.91 & 126.06 & 65.86 & 256.90 & 30.54 & 221.58 & 4 \\
\hline CO emission 2013 & 153.98 & 78.83 & 51.24 & 229.40 & 0 & 167.91 & $6 / 4$ \\
\hline CO emission 2019 & 125.2 & 55.56 & 37.13 & 187.18 & 0 & 130.59 & $5 / 3$ \\
\hline $\mathrm{CO}_{2}$ emission 2005 & $117,406.3$ & $107,725.4$ & $46,008.6$ & $141,321.0$ & $60,068.9$ & $155,381.3$ & 3 \\
\hline $\mathrm{CO}_{2}$ emission 2013 & $111,522.8$ & $101,313.7$ & $45,424.9$ & $137,384.7$ & $55,333.7$ & $147,293.6$ & $2 / 2$ \\
\hline $\mathrm{CO}_{2}$ emission 2019 & $100,594.9$ & $75,170.5$ & $49,257.4$ & $126,316.1$ & $36,641.1$ & $113,699.8$ & $4 / 3$ \\
\hline
\end{tabular}

Note: $M e-Q$ and $M e+Q$ are respectively the lower and upper limits of the typical range of the variation of emissions. If the value of the lower limit of the typical range of variation was negative, the value 0 was entered; $K$-number of voivodeships exceeding the $M e+Q$ level from the current year, K1 number of voivodeships exceeding the $M e+Q$ level from 2005.

Achieving the goal of reducing emissions of gaseous and dust pollutants requires, among other things, the effective implementation of air protection programs and improvement of the air quality management system at each level of management. For this reason, the authors considered the level of expenditure on fixed assets connected with new 
combustion technologies and the reduction of gaseous and dust pollutants in individual voivodeships in 2005, 2013, and 2019. We also analyzed the sources of financing expenditure on fixed assets for environmental protection, especially in terms of using financial sources from ecological funds or from abroad. On this basis, the authors constructed synthetic indicators for the development of voivodeships in Poland in the analyzed years in the area of economic effects (cf. Figure 2). The values of the synthetic measure of development in the area of economic effects presented in the Figure 2 show a clear downward trend, as in all voivodeships, the values of this measure in 2019 were lower than in 2005 . The average value of the synthetic measure was 0.3157 in 2005, 0.2692 in 2013, and only 0.2063 in 2019 . The Lubelskie voivodeship is an exception. In 2019, it tripled expenditure on environmental protection from foreign funds compared to 2013, and in 2013, it doubled foreign funds allocated to environmental protection compared to 2005. The obtained funds contributed to a significant increase in outlays on fixed assets connected mainly with new combustion technologies, reduction of gaseous pollutants, and energy saving. In the long term, the Opolskie and Ślaskie voivodeships were the ones that showed the highest values of the synthetic development index most often - the average value of the indicator in 2005-2019 was, respectively, 0.3683 (Opolskie voivodeship) and 0.3652 (Śląskie voivodeship). This was due to, among other factors, a relatively better access to external sources of financing environmental protection investments in comparison to other voivodeships (financing from environmental funds, domestic credits and loans, foreign funds). Initially, these funds were intended mainly for investments related to combustion techniques and the reduction of dust pollution (2005). Later, the expenditure on the reduction of gaseous pollution and energy saving (2019) was increased. As a result, in the Śląskie voivodeship, revenues from air and climate protection fees (including fines for exceeding the permissible air pollutant emission) systematically decreased, in the Opolskie voivodeship in 2019 compared to 2013 or 2005, an increase in fees was recorded again. In 2019, the lowest values of the synthetic measure of development were recorded in the Wielkopolskie voivodeship (0.0884) and Kujawsko-Pomorskie voivodeship (0.1323). In these voivodeships, outlays on fixed assets for environmental protection, and in particular investments in new combustion techniques, reduction of dust and gaseous pollution were the lowest in Poland, with relatively higher air and climate protection fees.

It is worth emphasizing that in the 2011-2014 period, the Świętokrzyskie voivodeship showed high values of the development measure (from 0.3773 to 0.4205 ), which was connected with relatively high expenditure on fixed assets for combustion techniques, the reduction of dust pollution and energy saving. In comparison to other voivodeships, during this period, the Świętokrzyskie voivodeship received relatively considerable financial resources from abroad and environmental funds, which could be allocated to environmental protection. The analysis shows that the availability of external sources of financing investments in environmental protection as well as the expenditure on fixed assets for air protection were different in the analyzed period. This situation was not conducive to making decisions on long-term investments in low-emission modernization of production processes in enterprises that are particularly harmful to the environment.

The implementation of the important goal of maintaining favorable trends in the improvement of air quality should lead to a decrease in health risk related to the exposure of the inhabitants of individual voivodeships to airborne substances harmful to health, especially PM10 and PM2.5 particulate matter.

Analysis of the synthetic measure of development in the area of social effects presented in Figure 3 shows that in the majority of Polish voivodeships, the general condition of health of the inhabitants did not improve in 2019 compared to 2005. The average values of the social development indicator for Polish voivodeships in 2005, 2013, and 2019 were, respectively, $0.4965,0.4425$, and 0.4457 . The values of the synthetic development measure were higher in 2019 than in 2005 only in the following voivodeships: Lubelskie, Łódzkie, Małopolskie, Mazowieckie, and Podkarpackie. Moreover, in the Pomorskie, 
Śląskie, and Wielkopolskie voivodeships, the values of the synthetic measure in 2019 were higher than in 2013.

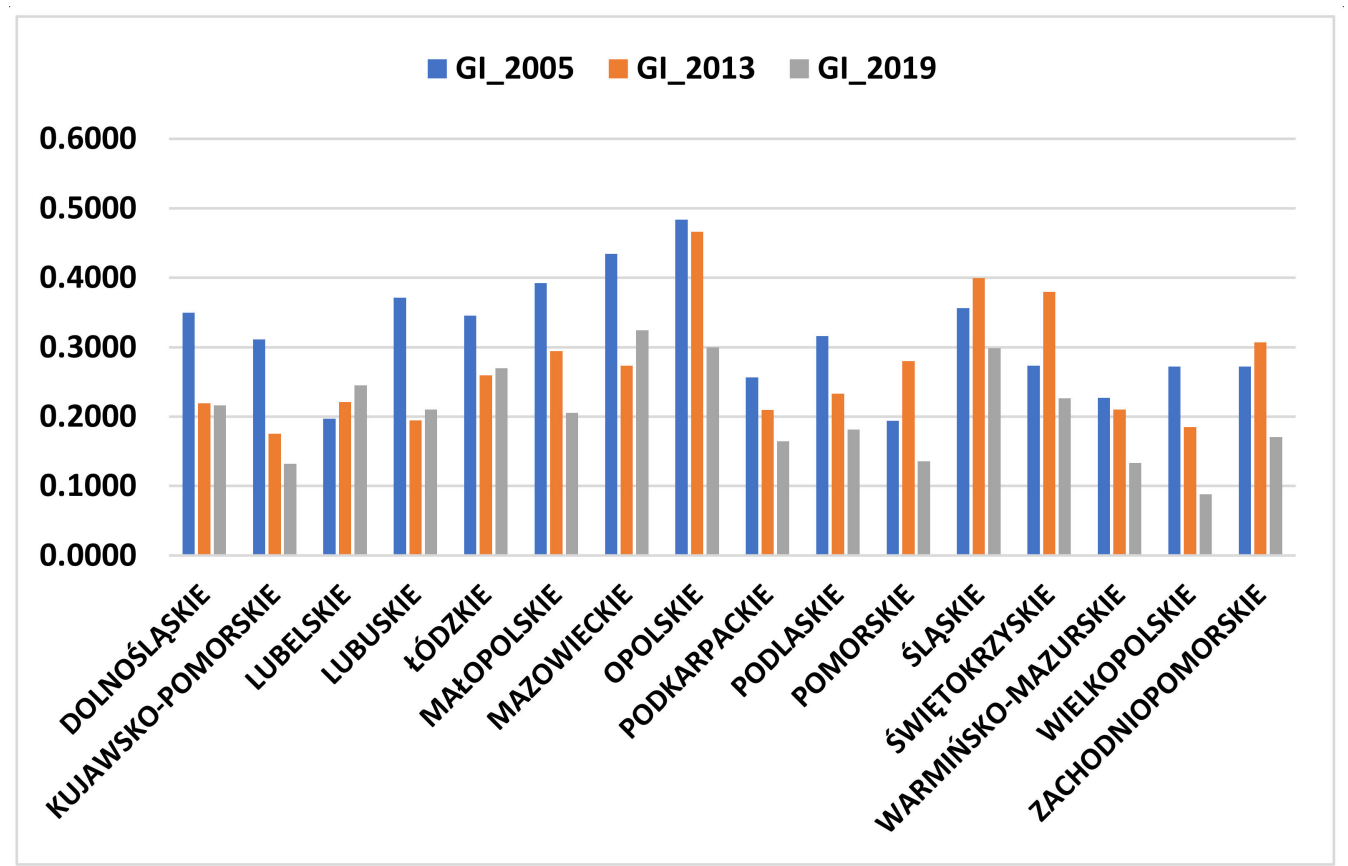

Figure 2. Values of the synthetic development measures relating to the economic effects for individual voivodeships in Poland in 2005, 2013, and 2019. Source: Own elaboration based on the data of the Central Statistical Office.

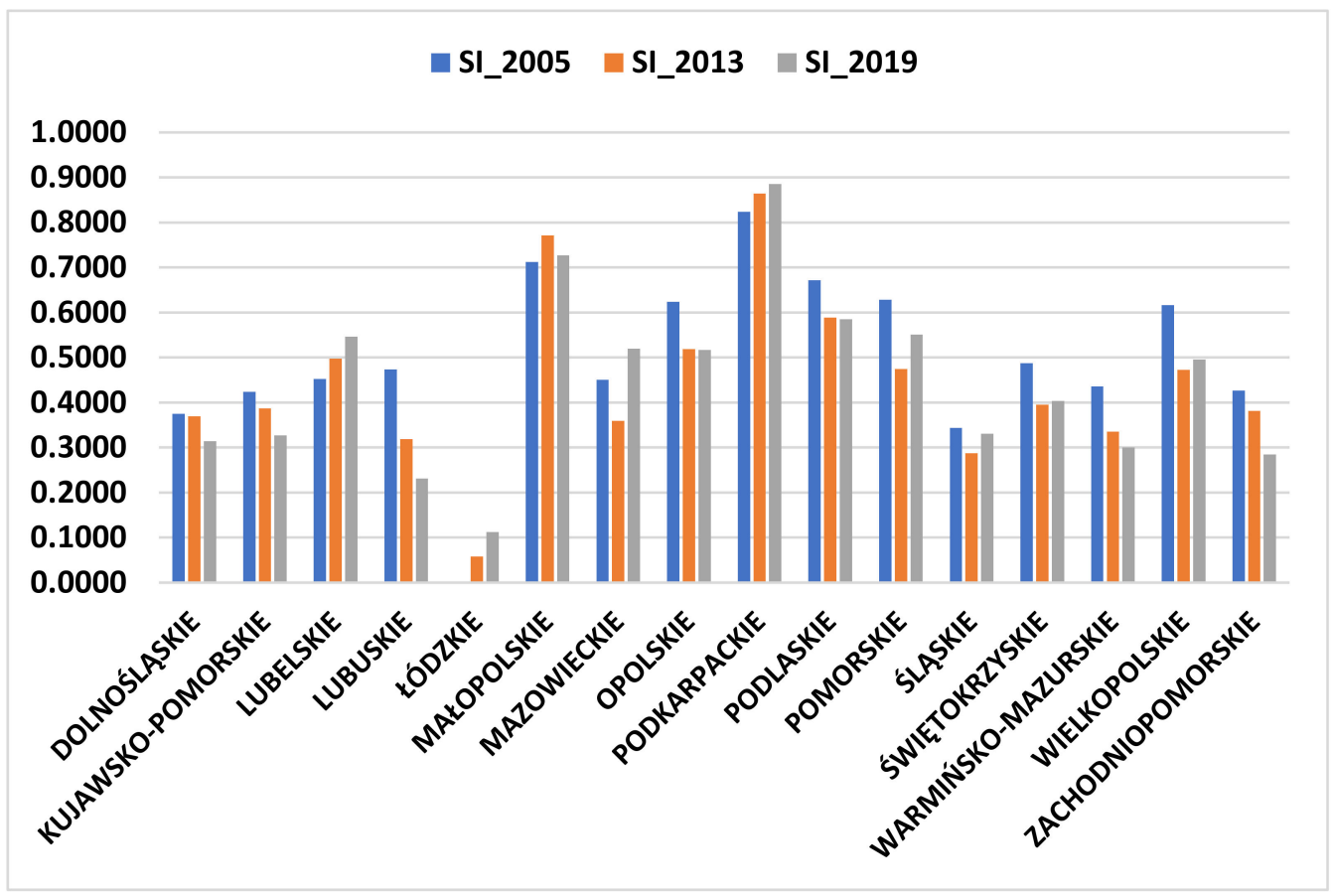

Figure 3. Values of the synthetic development measures connected with the social effects for individual voivodeships in Poland in 2005, 2013, and 2019. Source: Own elaboration based on the data of the Central Statistical Office.

Throughout the analysis period, the Łódzkie voivodeship showed the most similarity to the anti-reference object in terms of the value of the synthetic measure of development 
connected with the condition of the health of the population (average 0.0637). It was caused by relatively high mortality rates from diseases and malignant neoplasms of the respiratory system and cardiovascular diseases, i.e., diseases whose risk increases along with the increase in the emission of dusts and gases from the combustion of conventional fuels [48]. At the same time, the average life expectancy in this voivodeship was among the worst in Poland. In the years 2005-2019, the values of the synthetic measure illustrating the health of the population were the best for the Podkarpackie (an average of 0.8491) and Małopolskie (an average of 0.7560 ) voivodeships due to the relatively higher life expectancy in the populations of 15- and 45-year-olds, as well as lower death rates from respiratory diseases and respiratory malignant neoplasms.

The next step of the analysis was devoted to checking whether the values of the synthetic measures of development relating to the environmental, economic, and social effects of the activities of enterprises particularly harmful to the environment changed significantly in the three analyzed years. To verify the null hypothesis about the lack of significant differences in the values of individual synthetic measures of development in Polish voivodeships, the sign test and the Wilcoxon signed-rank test were used [58,59].

The results in Table 2 show that at the significance level of 0.05 , the null hypothesis about the lack of differences in the values of the environmental indicator in 2013 compared to 2005 (signs test and Wilcoxon signed-rank test) should be rejected. Previous analyses (cf. Table 1 and Figure 1) showed that the voivodeships were characterized by a general increase in the value of the synthetic measure of development describing the environmental effects in 2013 compared to 2005. Hence, there was a noticeable weakening of the negative impact of enterprises that are particularly harmful to the environment on the air quality in this period. At the significance level of 0.05 , there are also significant differences in the values of the synthetic development indicator relating to the economic aspects of environmental protection in individual voivodeships in 2013 compared to 2005. Similarly, at the significance level of 0.1 , the null hypothesis about the lack of differences in the values of the GI indicators in 2019 compared to 2013 and the SI indicators in 2013 compared to 2005 should be rejected. The analyses presented earlier (see Figure 2) show that the values of the synthetic measure relating to the economic effects in individual voivodeships in 2019 were lower than in 2013 and 2005. This confirms the initial observation that in 2019, compared to 2013 and 2005, the possibilities of financing investments for air quality protection and improving energy efficiency from external sources worsened.

Table 2. The sign test and the Wilcoxon signed-rank test for the synthetic development measures.

\begin{tabular}{ccccccc}
\hline Variable & $\mathbf{v}<\mathbf{V}$ & $\mathbf{Z}^{\prime}$ & $\boldsymbol{p}$-Value & $\mathbf{T}$ & $\mathrm{Z}$ & $p$-Value \\
\hline EI $2013 / 2005$ & 81.25000 & 2.250000 & 0.024449 & 16.00000 & 2.688856 & 0.007170 \\
\hline EI $2019 / 2013$ & 68.75000 & 1.250000 & 0.211300 & 40.00000 & 1.447846 & 0.147661 \\
\hline EI $2019 / 2005$ & 43.75000 & 0.250000 & 0.802587 & 49.00000 & 0.982467 & 0.325871 \\
\hline GI 2013/2005 & 31.25000 & 1.250000 & 0.211300 & 33.00000 & 1.809807 & 0.070327 \\
\hline GI $2019 / 2013$ & 25.00000 & 1.750000 & 0.080118 & 16.00000 & 2.688856 & 0.007170 \\
\hline GI 2019/2005 & 6.25000 & 3.250000 & 0.001154 & 2.00000 & 3.412779 & 0.000643 \\
\hline SI $2013 / 2005$ & 25.00000 & 1.750000 & 0.080118 & 23.00000 & 2.326895 & 0.019971 \\
\hline SI $2019 / 2013$ & 50.00000 & -0.25000 & 0.802587 & 67.00000 & 0.051709 & 0.958761 \\
\hline SI 2019/2005 & 31.25000 & 1.250000 & 0.211300 & 32.00000 & 1.861516 & 0.062672 \\
\hline
\end{tabular}

$\mathrm{v}<\mathrm{V}$-percentage of cases for which the synthetic indicator in a given year is higher (lower) than the indicator in the base year; $\mathrm{Z}^{\prime}-$ sign test statistic value; T-Wilcoxon test statistic value $(n \leq 25)$, Z-Wilcoxon test statistic value $(n>25)$.

The estimated measures describing the health of the population (social effects) of Polish voivodeships in 2013 were lower than in 2005 (see Figure 3). However, at the significance level of 0.05 , it cannot be confirmed that there are significant differences between the values of the synthetic measure of development describing the health of the 
inhabitants of individual voivodeships in 2019 compared to 2013 or 2005 (cf. Table 2). Accordingly, there is no clear direction of changes in the value of the synthetic measure reflecting the health of the inhabitants of Polish voivodeships in terms of their exposure to diseases caused by air pollution in 2005-2019.

The above-mentioned aspects of the environmental impact of enterprises that have a negative influence in air quality, as well as the availability of external sources of financing investments aimed at improving energy efficiency or reducing pollutant emissions, were reflected in the rankings of the voivodeships according to the values of the synthetic measures of development (cf. Table 3).

Table 3. Rankings of the voivodeships according to the synthetic development measures for the years 2005, 2013 , and 2019.

\begin{tabular}{|c|c|c|c|c|c|c|c|c|c|}
\hline \multirow{2}{*}{ Voivodship } & \multicolumn{3}{|c|}{2005} & \multicolumn{3}{|c|}{2013} & \multicolumn{3}{|c|}{2019} \\
\hline & EI & GI & SI & EI & GI & SI & EI & GI & SI \\
\hline Dolnośląskie & 4 & 6 & 14 & 4 & 11 & 11 & 5 & 7 & 12 \\
\hline Kujawsko-pomorskie & 3 & 9 & 13 & 7 & 16 & 9 & 7 & 15 & 11 \\
\hline Lubelskie & 9 & 15 & 9 & 9 & 10 & 5 & 11 & 5 & 5 \\
\hline Lubuskie & 15 & 4 & 8 & 12 & 14 & 14 & 10 & 8 & 15 \\
\hline Łódzkie & 16 & 7 & 16 & 16 & 8 & 16 & 16 & 4 & 16 \\
\hline Małopolskie & 10 & 3 & 2 & 5 & 5 & 2 & 4 & 9 & 2 \\
\hline Mazowieckie & 12 & 2 & 10 & 15 & 7 & 12 & 13 & 1 & 6 \\
\hline Opolskie & 13 & 1 & 5 & 11 & 1 & 4 & 14 & 2 & 7 \\
\hline Podkarpackie & 2 & 13 & 1 & 2 & 13 & 1 & 2 & 12 & 1 \\
\hline Podlaskie & 6 & 8 & 3 & 3 & 9 & 3 & 9 & 10 & 3 \\
\hline Pomorskie & 1 & 16 & 4 & 1 & 6 & 6 & 1 & 13 & 4 \\
\hline Śląskie & 14 & 5 & 15 & 13 & 2 & 15 & 12 & 3 & 10 \\
\hline Świętokrzyskie & 8 & 10 & 7 & 14 & 3 & 8 & 15 & 6 & 9 \\
\hline Warmińsko-mazurskie & 7 & 14 & 11 & 10 & 12 & 13 & 8 & 14 & 13 \\
\hline Wielkopolskie & 11 & 11 & 6 & 8 & 15 & 7 & 3 & 16 & 8 \\
\hline Zachodniopomorskie & 5 & 12 & 12 & 6 & 4 & 10 & 6 & 11 & 14 \\
\hline
\end{tabular}

For the rankings of voivodeships presented in Table 3, the values of Spearman rank correlation coefficients are estimated in Equation (7).

The analysis of the results presented in Table 4 can help formulate a conclusion about the existence of a positive and statistically significant correlation only between the values of the synthetic measures of development relating to the environmental indicator and the social indicator in 2013. This proves that the higher the position of a voivodeship in the ranking due to the reduction of the negative impact of energy-intensive enterprises on the environment, the higher the position of the voivodeship in the ranking connected with the health of its inhabitants. It is also worth paying attention to the statistically significant and negative correlation between the synthetic measures relating to the environmental and economic effects in 2005 and 2019. The voivodeships, which were high in the ranking in 2005 and 2019 due to the possibility of using external sources of financing investments in air protection and energy saving, were low in the ranking with respect to the degree of the reduction of dust and gaseous emissions by enterprises particularly harmful to the environment. The direction of the correlation may indicate the proper allocation of funds for air protection, as the largest pool of funds was allocated to the voivodeships that need them the most. No significant correlations were identified between the positioning of the voivodeships in the rankings according to the measures relating to the economic aspects of environmental protection and the health of the population.

\subsection{Estimation Results of Panel Data Models}

The first stage of the construction of panel models involves checking the stationarity of all variables. For this purpose, two first-generation panel unit root tests were used: the Levin, Lin and Chu [60], and the Im, Pesaran and Shin [61] test. 
Table 4. Spearman rank correlation coefficients for the rankings of the voivodeships based on the values of the synthetic measures of development.

\begin{tabular}{cccc}
\hline Pair of Indicators & Spearman Coefficient & Pair of Indicators & Spearman Coefficient \\
\hline GI-EI 2005 & $-0.624^{* *}$ & EI-SI 2019 & 0.371 \\
\hline GI-EI 2013 & -0.241 & GI-SI 2005 & -0.103 \\
\hline GI-EI 2019 & $-0.768^{* *}$ & GI-SI 2013 & 0.035 \\
\hline EI-SI 2005 & 0.276 & GI-SI 2019 & -0.053 \\
\hline EI-SI 2013 & $0.659^{* *}$ & G &
\end{tabular}

Note: Due to the purpose of the research, the table presents only Spearman correlation coefficients for pairs of indicators corresponding to the various aspects of development: environmental, economic, and social. The ** symbol indicates the significance of the result at the level of $5 \%$.

When analyzing the results presented in Table 5, it can be observed that at the significance level of 0.05 for all the studied variables, the null hypothesis assuming common unit root process in $L L C$ test had to be rejected. The stationarity of all variables except GVA can also be confirmed in the IPS test, verifying the null hypothesis about individual unit root process. The second-generation panel unit-root test was also carried out to verify whether the $L L C$ and IPS test results may be subject to potential cross-sectional dependences in the panel data [62]. The results of the Pesaran CIPS test confirm the stationarity of all of the studied variables except the GVA variable, for which at the significance level of 0.1 , there are no grounds to reject the null hypothesis assuming a unit root process with cross-section dependence. For this reason, a logarithmic transformation of the variable controlling the effect of the industrialization of a voivodeship was used in the model (8). According to the results of $L L C$ and Pesaran CIPS tests, the variable is stationary (Table 5).

Table 5. Descriptive statistics and unit root tests.

\begin{tabular}{|c|c|c|c|c|c|}
\hline Statistics & EI & GI & SI & \multicolumn{2}{|c|}{$\begin{array}{c}\text { GVA I lnGVA } \\
\text { [(Thousand) } 2005 \text { PLN per Capita] }\end{array}$} \\
\hline Mean & 0.507753 & 0.257105 & 0.470732 & \multicolumn{2}{|c|}{6.730628} \\
\hline Median & 0.515857 & 0.246124 & 0.449889 & \multicolumn{2}{|c|}{6.468714} \\
\hline Std. Dev. & 0.109429 & 0.085192 & 0.184669 & \multicolumn{2}{|c|}{2.096668} \\
\hline Observations & 240 & 240 & 240 & \multicolumn{2}{|c|}{240} \\
\hline LLC & $\begin{array}{c}-3.80779 \\
{[0.0001]}\end{array}$ & $\begin{array}{c}-6.09897 \\
{[0.0000]}\end{array}$ & $\begin{array}{c}-1.81111 \\
{[0.0351]}\end{array}$ & $\begin{array}{c}-2.50461 \\
{[0.0061]}\end{array}$ & $\begin{array}{c}-4.31882 \\
{[0.000]}\end{array}$ \\
\hline IPS & $\begin{array}{c}-2.10973 \\
{[0.0174]}\end{array}$ & $\begin{array}{c}-3.78438 \\
{[0.0001]}\end{array}$ & $\begin{array}{c}-1.67813 \\
{[0.0467]}\end{array}$ & $\begin{array}{l}1.77363 \\
{[0.9619]}\end{array}$ & $\begin{array}{c}-0.01834 \\
{[0.4927]}\end{array}$ \\
\hline Pesaran CIPS & $-3.27468^{* * *}$ & $-19.31223^{* * *}$ & -2.19038 * & 1.88543 & $-3.23531^{* * *}$ \\
\hline
\end{tabular}

Notes: LLC-Levin, Lin, and Chu (2002) test, IPS-Im, Pesaran, and Shin W-stat (2003) test, $p$-value in brackets; Schwarz Information Criterion (SIC) is used for lag selection; ${ }^{* * *}$ significant at the $1 \%$ level, ${ }^{* *}$ significant at the $5 \%$ level, * significant at the $10 \%$ level-the Pesaran CIPS test.

In the next stage of modeling, the authors verified the possibility of using static panel models to describe the relationship between the well-being of society and the environmental and economic effects accompanying the activities of enterprises that are particularly harmful to the environment in Poland in 2005-2013. Due to the presence of autocorrelation dependence in the rest of these models, and to the fact that static panel estimations do not consider the possible effect of past social synthetic measure values on its current value, the model parameters were estimated using the panel data approach [26]. Therefore, in order to estimate the regression (8), we used the dynamic generalized method of moments $(G M M)$ estimator with two-step robust standard errors $[56,57,63]$. This method enables for control the potential endogeneity of the independent and control variables derived 
from the existence of unobserved heterogeneity, reciprocal causality, and the presence of persistent series [55]. Various specifications of the model (8) were estimated in order to check the robustness of the results (cf. Table 6). The basic one (specification S1 and S2) takes into account only the impact of environmental and economic effects on the well-being of society. Another one adds control variables to the relationship describing the impact of just the environmental effects on social effects (specification S3 and S4). There were also specifications describing all three dimensions of enterprise activity, taking into account a set of control variables (specification S5 and S6). A similar strategy for modeling was presented by Horváthová [44]. Table 6 presents the results for the best models taking into account a one-year delay in the response of the population's health to changes in environmental and economic indicators related to the activities of environmentally harmful enterprises (specification S2, S4, and S6). They were compared with models in which the regressors are current and lagged EI or GI variables (specification S1, S3, and S5) in order to show the presence of a strong inter-temporal effect in the analyzed relationship. This is evidenced by statistically insignificant parameters for the unlagged EI and GI variables ( $\beta_{0}$ and $\gamma_{0}$ in specifications S1, S3, and S5), as well as statistically significant parameters at their first lags ( $\beta_{1}$ and $\gamma_{1}$ in specifications $\mathrm{S} 2$, S4, and S6).

The obtained results correspond to the results of other studies that show the existence of inter-temporal effects between the pro-environmental activities and the economic results of enterprises. Horváthová [44] proved that the increase in pollutant emissions after two years worsened the financial results of enterprises in the Czech Republic. Martí-Ballester [55] showed that outlays on research and development in the field of renewable energy sources with a one-year lag have a positive impact on corporate financial performance.

Moreover, the results of the panel models estimation presented in Table 6 indicate that in each case, the parameter $\gamma_{1}\left(G I_{i, t-1}\right)$ is statistically significant. This allows us to conclude that increasing the possibilities of financing investments in the low-emission development of the region, including the modernization of enterprises through reducing dust and gaseous pollution and reducing their energy consumption (GI index), significantly improves the well-being of society only in the following year. The previous static analysis carried out for the three selected years did not confirm the occurrence of correlation relationships between the ranking of voivodeships for the current values of the synthetic SI and GI measures, which was reflected in the results for panel models. Comparing the estimates of the parameters $\beta_{1}\left(E I_{\mathrm{i}, \mathrm{t}-1}\right)$ and $\gamma_{1}\left(G I_{\mathrm{i}, \mathrm{t}-1}\right)$ for specifications $S 2$ and $S 6$, it can be observed that the environmental effects had a stronger impact on the health of population than the economic effects. The $\beta_{1}$ parameters in specifications $S 2, S 4$, and $S 6$ are statistically significant at the significance level of 0.01 (Table 6). This means that activities undertaken by plants that are harmful to the environment, aimed at limiting the reduction of dust and gaseous emissions and increasing the share of renewable energy in the energy consumption structure, should result in an improvement in the health of inhabitants in the following year. The majority of previous studies analyzed the relationship between environmental effects and financial results of enterprises, and the results of panel model estimates for this relationship are not unambiguous. For example, Fan et al. [41] pointed out that the low-emission transformation of the Chinese economy and its intensive development put pressure on the companies but at the same time provide them with opportunities to reduce their energy intensity, which will ultimately improve their financial results. Ruggiero and Lehkonen [42] found that the relationship between the increase in renewable energy production and the profitability of companies depends on the degree of the negative environmental impact of the company. Companies with high $\mathrm{CO}_{2}$ emissions can benefit more from an increase in $R E S$ production. This result is very interesting from the perspective of our research and the need to reduce energy consumption by the companies we analyzed. On the other hand, Gonenc and Scholtens [43] showed that companies from the fuel sector with better financial results emit more pollutants into the air. In their view, this may mean that the efforts of fossil fuels firms do not appear to be sufficient to improve environmental performance and 
that there are trade-offs and synergies between environmental and financial effects that may be sector specific (chemicals, coal or oil and gas).

Table 6. Results of panel regression models.

\begin{tabular}{|c|c|c|c|c|c|c|}
\hline Coefficient/Test & $\begin{array}{c}\text { S1-Basic } \\
\text { Specification }\end{array}$ & $\begin{array}{c}\text { S2-Basic } \\
\text { Specification }\end{array}$ & $\begin{array}{l}\text { S3_-Social and } \\
\text { Environmental } \\
\text { Effects }\end{array}$ & $\begin{array}{c}\text { S4-Social and } \\
\text { Environmental } \\
\text { Effects }\end{array}$ & $\begin{array}{c}\text { S5-Social, } \\
\text { Environmental, } \\
\text { Economic } \\
\text { Effects }\end{array}$ & $\begin{array}{c}\text { S6-Social, } \\
\text { Environmental, } \\
\text { Economic } \\
\text { Effects }\end{array}$ \\
\hline$\rho_{1}\left(\mathrm{SI}_{\mathrm{i}, \mathrm{t}-1}\right)$ & $\begin{array}{c}0.345703 \\
{[0.2126]}\end{array}$ & $\begin{array}{c}0.716213^{* * *} \\
{[0.0001]}\end{array}$ & $\begin{array}{c}0.56852^{* * *} \\
{[0.0001]}\end{array}$ & $\begin{array}{c}0.621634^{* * *} \\
{[0.0001]}\end{array}$ & $\begin{array}{l}0.247851 \\
{[0.1794]}\end{array}$ & $\begin{array}{c}0.621069^{* * *} \\
{[0.0004]}\end{array}$ \\
\hline$\beta_{0}\left(\mathrm{EI}_{\mathrm{i}, \mathrm{t}}\right)$ & $\begin{array}{l}0.646941 \\
{[0.1044]}\end{array}$ & - & $\begin{array}{l}0.227812 \\
{[0.4332]}\end{array}$ & - & $\begin{array}{l}0.62613^{*} \\
{[0.0766]}\end{array}$ & - \\
\hline$\beta_{1}\left(\mathrm{EI}_{\mathrm{i}, \mathrm{t}-1}\right)$ & $\begin{array}{c}0.0587319 \\
{[0.7775]}\end{array}$ & $\begin{array}{c}0.301430^{* * *} \\
{[0.0001]}\end{array}$ & $\begin{array}{l}0.23379 \\
{[0.2780]}\end{array}$ & $\begin{array}{c}0.411967 * * * \\
{[0.0004]}\end{array}$ & $\begin{array}{c}0.239337 \\
{[0.4496]}\end{array}$ & $\begin{array}{c}0.425755^{* * *} \\
{[0.0091]}\end{array}$ \\
\hline$\gamma_{0}\left(\mathrm{GI}_{\mathrm{i}, \mathrm{t}}\right)$ & $\begin{array}{c}0.0245438 \\
{[0.4852]}\end{array}$ & - & - & - & $\begin{array}{l}0.082309 \\
{[0.4215]}\end{array}$ & - \\
\hline$\gamma_{1}\left(\mathrm{GI}_{\mathrm{i}, \mathrm{t}-1}\right)$ & $\begin{array}{c}0.143207^{* *} \\
{[0.0438]}\end{array}$ & $\begin{array}{c}0.0676436^{* *} \\
{[0.0414]}\end{array}$ & - & - & $\begin{array}{c}0.22584^{* * * *} \\
{[0.0018]}\end{array}$ & $\begin{array}{c}0.120380^{* * *} \\
{[0.0001]}\end{array}$ \\
\hline$\phi_{0}\left(\operatorname{lnGVA} \mathrm{i}_{\mathrm{i}, \mathrm{t}}\right)$ & - & - & $\begin{array}{c}-0.110389 * * \\
{[0.0341]}\end{array}$ & $\begin{array}{c}-0.06627^{* * *} \\
{[0.0001]}\end{array}$ & $\begin{array}{l}-0.13347 \\
{[0.1933]}\end{array}$ & $\begin{array}{c}-0.06712^{* * *} \\
{[0.0004]}\end{array}$ \\
\hline$\phi_{1}\left(\operatorname{lnGVA}_{, \mathrm{it}-1}\right)$ & - & - & $\begin{array}{c}-0.032594 \\
{[0.5229]}\end{array}$ & - & $\begin{array}{c}0.0062714 \\
{[0.9434]}\end{array}$ & - \\
\hline$\alpha_{0}$ & $\begin{array}{l}-0.097^{* *} \\
{[0.0391]}\end{array}$ & $\begin{array}{c}-0.0426982 \\
{[0.2186]}\end{array}$ & $\begin{array}{c}0.105425^{* *} \\
{[0.0498]}\end{array}$ & $\begin{array}{c}0.090205^{* *} \\
{[0.0346]}\end{array}$ & $\begin{array}{l}0.07216 \\
{[0.3602]}\end{array}$ & $\begin{array}{l}0.057563 \\
{[0.2955]}\end{array}$ \\
\hline$\alpha_{1}\left(D_{2013, t}\right)$ & - & - & $\begin{array}{c}-0.049424^{* * *} \\
{[0.0001]}\end{array}$ & $\begin{array}{c}-0.050449^{* * *} \\
{[0.0001]}\end{array}$ & $\begin{array}{c}-0.05507^{* * *} \\
{[0.0001]}\end{array}$ & $\begin{array}{c}-0.05739^{* * *} \\
{[0.0001]}\end{array}$ \\
\hline$\alpha_{2}\left(D_{\mathrm{E}, \mathrm{it}-1}\right)$ & - & - & $\begin{array}{c}0.015502 \\
{[0.4218]}\end{array}$ & $\begin{array}{l}0.011387 \\
{[0.4271]}\end{array}$ & $\begin{array}{l}0.010375 \\
{[0.5648]}\end{array}$ & $\begin{array}{l}0.007147 \\
{[0.7015]}\end{array}$ \\
\hline $\mathrm{AR}(1)$ & $-1.86[0.0629]$ & $\begin{array}{c}-2.92359 \\
{[0.0035]}\end{array}$ & $\begin{array}{l}-3.2875 \\
{[0.0010]}\end{array}$ & $\begin{array}{c}-3.07268 \\
{[0.0021]}\end{array}$ & $\begin{array}{l}-2.06958 \\
{[0.0385]}\end{array}$ & $\begin{array}{c}-3.08849 \\
{[0.0020]}\end{array}$ \\
\hline $\operatorname{AR}(2)$ & $\begin{array}{c}-0.113037 \\
{[0.9100]}\end{array}$ & $\begin{array}{c}0.578743 \\
{[0.5628]}\end{array}$ & $1.82245[0.0684]$ & $1.78138[0.0748]$ & $1.25041[0.2111]$ & 1.8471 [0.0647] \\
\hline Sargan test & $12.7513[1.0000]$ & $14.6824[1.0000]$ & 12.6957 [1.0000] & $13.4983[1.000]$ & 8.86812 [1.0000] & 13.428 [1.0000] \\
\hline Wald test (joint) & $294.088[0.0000]$ & $411.174[0.0000]$ & $608.376[0.0000]$ & $536.261[0.0000]$ & $556.711[0.0000]$ & $367.113[0.0000]$ \\
\hline
\end{tabular}

Notes: Gretl uses in the GMM system estimation process the $H$ matrix being to reproduce used by respectively Ox/DPD [64]; *** significant at the $1 \%$ level, ** significant at the $5 \%$ level, * significant at the $10 \%$ level, $A R(1)$-Arellano-Bond test for the autocorrelation effect in first differences, $A R(2)$-Arellano-Bond test for the autocorrelation effect in second differences, $p$-values in brackets.

The authors of the present study focused on an extremely important and relatively rarely modeled issue of the impact of environmentally harmful enterprises on the health of people. Since the different degree of the industrialization of Polish voivodeships may affect the examined relationship, a control variable $\ln G V A$ was introduced. The parameter estimates for this variable are statistically significant at the significance level of 0.05 , and the negative sign of the parameter indicates that the increase in the value of production in the industry and energy sectors per capita translates into the deterioration of the well-being of society. The analyzed plants that are harmful to the environment represent the industrial and energy sectors; therefore, the degree of industrialization in the voivodeships and the size of energy-consuming production will have a negative impact on the health of inhabitants. On the other hand, the estimates of the parameters for the dummy variable $D_{E}$, which differentiates the voivodeships according to the strong concentration of plants harmful to the environment, were statistically insignificant, which is a rather surprising effect. We suppose that it may result from the very construction of this variable. The reduction of the synthetic measure of development describing the health of the population in 2013 compared to 2005, which was observed in the first part of the study, was also reflected in panel modeling because the parameter for the dummy variable $D_{2013}$ is statistically significant and negative (Table 6). Finally, it should be emphasized that the persistence of the values of the synthetic variable describing the well-being of society is strong in the 
series, as indicated by the positive and statistically significant value of the parameter $\rho_{1}$ $\left(S I_{i, t-1}\right)$. This justifies the need to use dynamic panel models to describe the relationship between the environmental, economic, and social effects of enterprises that are harmful to the environment.

Bond tests for the autocorrelation effect in the first $(A R(1))$ and second $(A R(2))$ differences of residuals. The assumptions of the model construction require that there is no autocorrelation of the residual component of order 2 and higher. This condition was positively verified for each model at the significance level of 0.05 . On the other hand, the high $p$-value in the Sargan test for overidentifying restriction casts doubt on the correctness of the selection of instruments used for modeling. For this reason, the estimation results for selected model specifications were repeated using the two-step GMM system estimator under the assumption of orthogonal deviations transformation. The obtained results are presented in Table 7.

Table 7. Results of panel regression models—GMM system, orthogonal differences.

\begin{tabular}{cccc}
\hline Dependent Variable & $\begin{array}{c}\text { S2-Basic } \\
\text { Specification }\end{array}$ & $\begin{array}{c}\text { S4-Social and } \\
\text { Environmental } \\
\text { Effects }\end{array}$ & $\begin{array}{c}\text { S6-Social, } \\
\text { Environmental, } \\
\text { Economic Effects }\end{array}$ \\
\hline$\rho_{1}\left(\mathrm{SI}_{\mathrm{i}, \mathrm{t}-1)}\right)$ & $0.819406^{* * *}[0.000]$ & $0.659888^{* * *}[0.000]$ & $0.629948^{* * *}[0.001]$ \\
\hline$\beta_{1}\left(\mathrm{EI}_{\mathrm{i}, \mathrm{t}-1}\right)$ & $0.169356[0.190]$ & $0.340466^{*}[0.072]$ & $0.345664^{* *}[0.035]$ \\
\hline$\gamma_{1}\left(\mathrm{GI}_{\mathrm{i}, \mathrm{t}-1}\right)$ & $0.0337076[0.651]$ & - & $0.0969681[0.310]$ \\
\hline$\phi_{0}\left(\mathrm{lnVA}_{\mathrm{i}, \mathrm{t}}\right)$ & - & $-0.0456059[0.195]$ & $-0.0300258[0.266]$ \\
\hline$\alpha_{0}$ & $-0.0123760[0.860]$ & $0.0774981[0.233]$ & $0.0367818[0.615]$ \\
\hline$\alpha_{1}\left(\mathrm{D}_{2013, t}\right)$ & - & $-0.0505751^{* * *}[0.000]$ & $-0.0504264^{* * *}[0.006]$ \\
\hline$\alpha_{2}\left(\mathrm{D}_{\mathrm{E}, \mathrm{it}-1}\right)$ & - & $-0.0152285[0.860]$ & $-0.0155184[0.799]$ \\
\hline $\mathrm{AR}(1)$ & $-2.744[0.006]$ & $-2.800[0.005]$ & $-2.819[0.005]$ \\
\hline AR(2) & $0.6029[0.547]$ & $1.653[0.098]$ & $1.637[0.102]$ \\
\hline Sargan test & $14.52[1.000]$ & $12.83[1.000]$ & $12.13[1.000]$ \\
\hline Wald test (joint) & $68.74[0.000]$ & $237.9[0.000]$ & $142.8[0.000]$ \\
\hline
\end{tabular}

Notes: the 2-step GMM system estimator use small-sample correction of Windmeijer (2005), ${ }^{* * *}$ significant at the $1 \%$ level, ** significant at the $5 \%$ level, * significant at the $10 \%$ level, AR(1)—Arellano-Bond test for the autocorrelation effect in first differences, $A R(2)$-Arellano-Bond test for the autocorrelation effect in second differences, $p$-values in brackets.

Comparing the obtained results to the previous ones, it can be observed that the parameters $\gamma_{1}\left(G I_{\mathrm{i}, \mathrm{t}-1}\right)$ are no longer statistically significant, which is similar to the parameters of the control variable $\ln G V A$ that described the effect of the degree of industrialization of a voivodeship. At the significance level of 0.1 , one can conclude about a significant and positive impact of the environmental effects of the activity of enterprises on the wellbeing of society. Sargan's test results remained unchanged, which is why the obtained results of calculations should be additionally verified, which will be the subject of our further research.

The results for panel models can be an interesting supplement to the static ratio analysis for the three selected years 2005, 2013, and 2019, which was presented in the previous part of this work. The results allow us to conclude that there are additional inter-temporal relationships between the well-being of society and environmental and economic effects connected with the activities of enterprises that are particularly harmful to the environment in Poland in 2005-2019. The conducted research also indicates the need to find new methods of analyzing the relationships between the environmental and economic effects achieved by enterprises that are particularly harmful to the environment and the health of the society. Taking into account the increasing industrialization of world economies, the impact of enterprises creating these economies on societies is of great impor- 
tance, especially considering the fact that despite the increased involvement of economic entities in the protection of natural resources, the use of industrial raw materials is growing, causing the impact of enterprises on society, including health and life of the population, to remain negative. In Poland, hard coal and lignite accounted for approximately 93\% of the fuels used for the production of electricity by the commercial power industry in 2017. Moreover, individual voivodeships in Poland are characterized by a significant diversification in terms of the consumption of fuels and energy carriers, which is the result of the economic structure in a given voivodeship and the availability of individual energy carriers. Although new legal regulations that use various environmental management instruments are introduced regularly, in 2019, compared to 2005, the consumption of hard coal increased in some provinces-Mazowieckie (by 27.1\%), Opolskie (by 15\%), and Świętokrzyskie (by 24.1\%). According to the data published by the Central Statistical Office, in 2019, compared to 2005, electricity consumption increased in all Polish voivodeships, with the most significant increase in the Świętokrzyskie voivodeship (by 59.8\%) [65]. Such a structure of the consumption of the carriers of energy generates relatively high emissions of toxic dusts, gases, and heavy metals, which have a negative impact on human health and climate change. As a result, energy and industrial companies are increasingly experiencing pressure from local communities and regulators to reduce emissions from their production processes. The low-emission transformation of enterprises in Poland should be accompanied by, among other things, increasing energy efficiency and investments in renewable energy sources, supplying enterprises with devices for reducing dust and gaseous pollution, and finding new tools for identifying the environmental and social effects accompanying their activities.

\section{Conclusions}

The article examines the impact of the environmental and economic effects of enterprises that are particularly harmful to the environment on the health and life of people. Polish voivodeships, the basic administrative unit of the country, were the subject of the study. A panel model was used to study the dependence, and the variables used in the model were synthetic variables estimated by the linear ordering method. Based on the environmental synthetic indicators, it has been possible to point out the Polish voivodeships in which enterprises that are particularly harmful to the environment were able to reduce the emissions of dust and gaseous pollutants in the 2005-2019 period. These changes were often accompanied by an increase in the production of energy from renewable sources and increasing the supply of plants with devices to contain gaseous and dust pollutants. The conducted analysis showed that in most Polish voivodeships, the values of the synthetic measure in the area of economic effects in 2019 were lower than in 2013 and 2005. This decreasing availability of external sources of financing investments in environmental protection and improving energy efficiency was not conducive to making decisions on the long-term investments in low-emission modernization of production processes in enterprises that are particularly harmful to the environment. Moreover, the comparison of positioning the voivodeships in the rankings according to social, economic, and environmental synthetic measures allows formulating the conclusion that the reduction of the negative impact of energy-intensive enterprises on the environment has been associated with the higher position of the voivodeship in the ranking connected with the health of its inhabitants. It has been also seen that the largest pool of funds was allocated to the voivodeships that need them the most, as these voivodeships were low in the ranking with respect to the degree of the reduction of dust and gaseous emissions by enterprises particularly harmful to the environment. The results for dynamic panel models additionally indicated the existence of the inter-temporal relationships between the well-being of society and environmental and economic effects connected with the activities of enterprises that are particularly harmful to the environment in Poland in 2005-2019. Namely, increasing the possibilities of financing investments in low-emission development of the region may improve the well-being of society only in the following year. It is showed that the 
environmental effects had a stronger impact on the health of population than the economic effects. This means that air pollutants' emission reduction activities undertaken by plants that are harmful to the environment should result in an improvement in the health of inhabitants in the following year. These results support the previous research on the existence of inter-temporal relations between the environmental and economic dimensions of the activities carried out by enterprises. Horváthová [44] and Martí-Ballester [55] indicated at the lagged character of the adjustment processes between environmental performance and economic effects of the production activities of companies.

It is worth stressing that analyzed synthetic measures designed on the basis of a set of diagnostic variables corresponding to sustainable development indicators may be useful tools supporting the decision-making process in the area of enterprise management in terms of ecological, economic, and social goals. Sustainable development takes into account the combination of three groups of factors: economic, environmental, and social. For this reason, the integrated order, which assumes the coherent and simultaneous creation of three orders: social, economic, and environmental, was adopted as the basis for grouping indicators of sustainable enterprise management. The economic and environmental order reflect the ecological and economic context of enterprise management, and the social order reflects the well-being of society. The activity of enterprises, especially the ones that are especially burdensome for the environment, should take into account all these rules, and the management of enterprises should focus not only on the economic but also environmental and social effects. Our views are similar to Ruggiero and Lehkonen [42], who stressed that the low-carbon modernization of production processes and transformation directed to the RES development should be profitable especially for companies with high $\mathrm{CO}_{2}$ emissions. Moreover, the research on welfare shows the positive impact of industrialization on the quality of life [66]. Yet, it is the decisions of enterprises that directly affect the level of social welfare. These decisions are related to the implementation of various types of technologies, including low-emission technologies [67]. However, one should remember that each decision involves certain costs that may be too high for companies.

Taking into account our empirical findings and previous research presented in the literature review, we can summarize that the activities of enterprises should be oriented not only to economic and environmental goals but also on social goals, especially those connected with the pursuit of prosperity. In the process of creating the prosperity of society, one should take into account the nuisance of economic activity resulting from air pollution, which influences the health and life of the population. The functioning of enterprises in conditions of uncertainty forces them to look for tools suitable for the study of mutual relationships between the basic factors shaping their activities. We think that the synthetic indicators constructed in the article, which take into account the multidimensionality of the factors constituting the three pillars of sustainable development, can be such tools. Their implementation in the management of enterprises will lead to a better planning and organization of activities in the context of economic, environmental, and social effects.

It is especially important in the period of the COVID-19 pandemic, which had a profound impact on environmental sustainability and social responsibility, as well as on the quality of people's lives. This disrupting period cannot be ignored in the ecological and economic analyses of the activity of enterprises. Changes in environmental awareness, sustainable consumption, and social behavior are the result of the long-term quarantine, social isolation, and the health crisis caused by the pandemic. The research conducted in this area shows that the COVID-19 pandemic positively influences environmental awareness, sustainable consumption, and social responsibility [68].

Moreover, research shows that the level of air pollution, including carbon dioxide pollution, was significantly reduced during the pandemic [69-73]. The reduction of the negative impact on the natural environment is connected with the limited activity of enterprises due to logistic difficulties, labor shortages, and lower demand due to the pandemic situation [74,75]. What is more, studies have shown a significant impact of COVID-19 on energy demand and consumption [76]. In the countries most affected 
by the pandemic, the energy consumption drop hovered within the $3-5 \%$ range in the first five months of the pandemic [77]. That is why enterprises should strive to find a balance between all three areas of their activity: environmental, energy, and social. Unfortunately, considering the duration of the COVID-19 pandemic, it is not possible to create a model taking account of the economic, environmental, and social effects achieved by enterprises during the pandemic. That puts a limit on the research, even more so that, as has been shown, the COVID-19 pandemic has a strong influence on both the functioning of enterprises and the health of society.

Taking into account the dynamically changing conditions of the functioning of enterprises, the basis for future research on the impact of enterprises that are particularly harmful to the environment on the health and life of residents will be the effects of the COVID-19 pandemic and the lockdown that accompanied it. There is a logical cause-and-effect relationship between the increasing pro-environmental awareness of people, the growing fear of health problems or death, and consumer behavior that has an impact on the operation and management of enterprises that are particularly harmful to the environment.

Author Contributions: Conceptualization, A.M.-L. and A.W.; methodology, A.M.-L. and A.W.; software, A.W.; validation, A.M.-L. and A.W.; formal analysis, A.M.-L. and A.W.; investigation, A.M.-L. and A.W.; resources, A.M.-L. and A.W.; data curation, A.W.; writing-original draft preparation, A.M.-L. and A.W.; writing-review and editing, A.M.-L. Both authors have read and agreed to the published version of the manuscript.

Funding: This research received no external funding.

Institutional Review Board Statement: Not applicable.

Informed Consent Statement: Not applicable.

Data Availability Statement: Not applicable.

Conflicts of Interest: The authors declare no conflict of interest.

\section{References}

1. Ministerstwo Środowiska Departament Ochrony Powietrza. Krajowy Program Ochrony Powietrza do Roku 2020 (z Perspektywa do 2030); Ministerstwo Środowiska Departament Ochrony Powietrza: Warszawa, Poland, 2015.

2. Bakst, D.; Tubb, K. A Proactive Environmental Policy Agenda for Congress and the Administration. Backgr. Herit. Found. 2020, 3555, 1-27.

3. Mishra, P.; Yadav, M. Environmental capabilities, proactive environmental strategy and competitive advantage: A naturalresource-based view of firms operating in India. J. Clean. Prod. 2021, 291, 125249. [CrossRef]

4. Potrich, L.; Cortimiglia, M.N.; Medeiros, J.F. A systematic literature review on firm-level proactive environmental management. J. Environ. Manag. 2019, 243, 273-286. [CrossRef] [PubMed]

5. Xu, X.; Wang, S.; Yu, Y. Consumer's intention to purchase green furniture: Do health consciousness and environmental awareness matter? Sci. Total Environ. 2020, 704, 135275. [CrossRef]

6. Li, X.; Zhang, D.; Zhang, T.; Ji, O.; Lucey, B. Awareness, energy consumption and pro-environmental choices of Chinese households. J. Clean. Prod. 2021, 279, 123734. [CrossRef]

7. Ko, E.; Hwang, J.K.; Kim, E.Y. Green marketing' functions in building corporate image in the retail setting. J. Bus. Res. 2013, 66, 1709-1715. [CrossRef]

8. Herbst, K.C.; Hannah, S.T.; Allan, D. Advertisement Disclaimer Speed and Corporate Social Responsibility: "Costs" to Consumer Comprehension and Effects on Brand Trust and Purchase Intention. J. Bus. Ethics 2013, 117, 297-311. [CrossRef]

9. Seggie, S.H.; Griffith, D.A. The moderating effects of economic and strategic relationship value in tolerating active and passive opportunism. J. Bus. Res. 2021, 128, 233-244. [CrossRef]

10. Mazutis, D. Supererogation: Beyond Positive Deviance and Corporate Social Responsibility. J. Bus. Ethics 2014, 119, 517-528. [CrossRef]

11. Li, X.; Nosheen, S.; Haq, N.U.; Gao, X. Value creation during fourth industrial revolution: Use of intellectual capital by most innovative companies of the world. Technol. Forecast. Soc. Chang. 2021, 163, 120479. [CrossRef]

12. Mouritsen, J. Driving growth: Economic Value Added versus Intellectual Capital. Manag. Account. Res. 1998, 9, 461-482. [CrossRef]

13. Seroka-Stolka, O. Ecological awareness and attitudes of managers. J. Ecol. Health 2011, 15, 71-76.

14. Tomić, T.; Schneider, D.R. Municipal solid waste system analysis through energy consumption and return approach. J. Environ. Manag. 2017, 203, 973-987. [CrossRef]

15. Ahn, K.; Chu, Z.; Lee, D. Effects of renewable energy use in the energy mix on social welfare. Energy Econ. 2021, 96, 105174. [CrossRef] 
16. Khastar, M.; Aslani, A.; Nejati, M. How does carbon tax affect social welfare and emission reduction in Finland? Energy Rep. 2020, 6, 736-744. [CrossRef]

17. Sowa, A. Społeczne uwarunkowania stanu zdrowia w Polsce. Zdr. Publiczne Zarzadzanie 2011, 2, $28-37$.

18. Nojszewska, E. Społeczno-ekonomiczne czynniki determinujące status zdrowotny społeczeństwa na przykładzie Polski. Ekon. Prawo Ochr. Zdrowia 2016, 1, 59-74.

19. Tang, W.; Li, H.; Chen, J. Optimizing carbon taxation target and level: Enterprises, consumers, or both? J. Clean. Prod. 2021, 282, 124515. [CrossRef]

20. Frugoli, P.A.; Almeida, C.M.V.B.; Agostinho, F.; Giannetti, B.F.; Huisingh, D. Can measures of well-being and progress help societies to achieve sustainable development? J. Clean. Prod. 2015, 90, 370-380. [CrossRef]

21. Tompkins, E.L.; Adger, W.N.; Boyd, E.; Nicholson-Cole, S.; Weatherhead, K.; Arnell, N. Observed adaptation to climate change: UK evidence of transition to a well-adapting society. Glob. Environ. Chang. 2010, 20, 627-635. [CrossRef]

22. Everard, M.; Kass, G.; Longhurst, J.; Ermgassen, S.; Girardet, H.; Stewart-Evans, J.; Wentworth, J.; Austin, K.; Dwyer, C.; Fish, R.; et al. Reconnecting society with its ecological roots. Environ. Sci. Policy 2021, 116, 8-19. [CrossRef]

23. Lundgren, T.; Zhou, W. Firm performance and the role of environmental management. J. Environ. Manag. 2017, 203, 330-341. [CrossRef] [PubMed]

24. Alipour, M.; Ghanbari, M.; Jamshidinavid, B.; Taherabadi, A. Does board independence moderate the relationship between environmental disclosure quality and performance? Evidence from static and dynamic panel data. Corp. Gov. 2019, 19, 580-610. [CrossRef]

25. Shao, Y. Does FDI affect carbon intensity? New evidence from dynamic panel analysis. Int. J. Clim. Chang. Strateg. Manag. 2018, 10, 27-42. [CrossRef]

26. Kapuria, C.; Singh, N. Determinants of sustainable FDI: A panel data investigation. Manag. Decis. 2019. Available online: https: / / www.emerald.com/insight/content/doi/10.1108/MD-01-2019-0064/full/pdf?casa_token=bI5RqtJbw7UAAAAA: hMDmPbfXUTF05bSbWcv6msJ55hZVd2pxGgWB0NikHIBArLSAxEWRJOaFW0cVaLRQWnyyPxwpxZOmLzvhQJPGaRAO4 s2ifkoR0WrFg5kO3LCgVagAwLA (accessed on 9 February 2021). [CrossRef]

27. Núñez-Velázquez, J.J.; Domínguez-Domínguez, J. A Proposal of a Synthetic Indicator to Measure Poverty Intensity, with an Application to EU-15 Countries. Soc. Study Econ. Inequal. 2007, 81, 1-28.

28. Laxe, F.G.; Bermúdez, F.M.; Palmero, F.M.; Novo-Corti, I. Sustainability and the Spanish port system. Analysis of the relationship between economic and environmental indicators. Mar. Pollut. Bull. 2016, 113, 232-239. [CrossRef]

29. Molinos-Senante, M.; Marques, R.C.; Pérez, F.; Gómez, T.; Sala-Garrido, R.; Caballero, R. Assessing the sustainability of water companies: A synthetic indicator approach. Ecol. Indic. 2016, 61, 577-587. [CrossRef]

30. Marti, L.; Puertas, R. Assessment of sustainability using a synthetic index. Environ. Impact Assess. Rev. 2020, 84, 106375. [CrossRef]

31. Zhang, Q.; Ma, Y. The impact of environmental management on firm economic performance: The mediating effect of green innovation and the moderating effect of environmental leadership. J. Clean. Prod. 2021, 292, 126057. [CrossRef]

32. Da Silva, P.C.; de Oliveira Neto, G.C.; Correia, J.M.F.; Tucci, H.N.P. Evaluation of economic, environmental and operational performance of the adoption of cleaner production: Survey in large textile industries. J. Clean. Prod. 2021, 278, 123855. [CrossRef]

33. Nishitani, K.; Kokubu, K. Can firms enhance economic performance by contributing to sustainable consumption and production? Analyzing the patterns of influence of environmental performance in Japanese manufacturing firms. Sustain. Prod. Consum. 2020, 21, 156-169. [CrossRef]

34. Farlinno, A.; Bernawati, Y. The company characteristics and environmental performance. Pol. J. Manag. Stud. 2020, 22, 111-126.

35. Mardijuwono, A.W.; Kurnianto, S.; Basuki, B.; Rahman, V.N.; Sucahyati, D. Managing the firm environmental and financial performance: New insight from government ownership. Pol. J. Manag. Stud. 2020, 21, 256-267. [CrossRef]

36. Wahyuni, D.; Ratnatunga, J. Carbon strategies and management practices in an uncertain carbonomic environment-Lessons learned from the coal-face. J. Clean. Prod. 2015, 96, 397-406. [CrossRef]

37. Damert, M.; Paul, A.; Baumgartner, R.J. Exploring the determinants and long-term performance outcomes of corporate carbon strategies. J. Clean. Prod. 2017, 160, 123-138. [CrossRef]

38. Böttcher, C.F.; Müller, M. Drivers, practices and outcomes of low-carbon operations: Approaches of German automotive suppliers to cutting carbon emissions. Bus. Strategy Environ. 2015, 24, 477-498. [CrossRef]

39. Boiral, O.; Henri, J.-F.; Talbot, D. Modeling the impacts of corporate commitment on climate change. Bus. Strategy Environ. 2012, 21, 495-516. [CrossRef]

40. Doda, B.; Gennaioli, C.; Gouldson, A.; Grover, D.; Sullivan, R. Are corporate carbon managements practices reducing corporate carbon emissions? Corp. Soc. Responsib. Environ. Manag. 2016, 23, 257-270. [CrossRef]

41. Fan, L.W.; Pan, S.J.; Liu, G.Q.; Zhou, P. Does energy efficiency affect financial performance? Evidence from Chinese energyintensive firms. J. Clean. Prod. 2017, 151, 53-59. [CrossRef]

42. Ruggiero, S.; Lehkonen, H. Renewable energy growth and the financial performance of electric utilities: A panel data study. J. Clean. Prod. 2017, 142, 3676-3688. [CrossRef]

43. Gonenc, H.; Scholtens, B. Environmental and Financial Performance of Fossil Fuel Firms: A Closer Inspection of their Interaction. Ecol. Econ. 2017, 132, 307-328. [CrossRef]

44. Horváthová, E. The impact of environmental performance on firm performance: Short-term costs and long-term benefits? Ecol. Econ. 2012, 84, 91-97. [CrossRef] 
45. Włodarczyk, A. Economic and environmental performance analysis of Polish energy companies. Glob. J. Environ. Sci. Manag. 2019, 5, 1-11.

46. Główny Urząd Statystyczny. Available online: Stat.gov.pl (accessed on 9 February 2021).

47. Wskaźniki Zrównoważonego Rozwoju Polski. Available online: https://stat.gov.pl/cps/rde/xbcr/gus/oz_wskazniki_ zrownowazonego_rozwoju_Polski_us_kat.pdf (accessed on 9 February 2021).

48. Raport Greenpeace: Wegiel Zabija. Available online: https://www.greenpeace.org/poland/raporty/2216/raport-greenpeacewegiel-zabija / (accessed on 9 February 2021).

49. Bank Danych Lokalnych. Available online: https://bdl.stat.gov.pl/BDL/dane/podgrup/temat/19/498/3177 (accessed on 9 February 2021).

50. Ekonomiczne Aspekty Ochrony Srodowiska. 2020. Available online: File:///C:/Users/Agata/AppData/Local/Temp/ ekonomiczne_aspekty_ochrony_srodowiska_2020.pdf (accessed on 9 February 2021).

51. Ochrona Środowiska 2006-2020. Available online: https:/ /stat.gov.pl/obszary-tematyczne/srodowisko-energia/srodowisko/ ochrona-srodowiska-2020,1,21.html (accessed on 9 February 2021).

52. Binderman, Z.; Borkowski, B.; Kozera, R.; Prokopenya, A.N.; Szczesny, W. On Mathematical Modelling of Synthetic Measures. Math. Model. Anal. 2018, 23, 699-711.

53. Walesiak, M. Porządkowanie liniowe z wykorzystaniem uogólnionej miary odległości GDM2 dla danych porządkowych i programu R*. Pr. Nauk. Uniw. Ekon. Wrocławiu Ekonom. 30 2011, 163, 9-18.

54. Doornik, J.A.; Hendry, D.F. Econometric Modelling. PcGive ${ }^{\mathrm{TM}} 14 ;$ Timberlake Consultants Ltd: London, UK, 2013; Volume III.

55. Martí-Ballester, C.-P. Sustainable energy systems and company performance: Does the implementation of sustainable energy systems improve companies' financial performance? J. Clean. Prod. 2017, 162, 535-550. [CrossRef]

56. Arellano, M.; Bond, S.R. Some tests of specification for panel data: Monte Carlo evidence and an application to employment equation. Rev. Econ. Stud. 1991, 58, 277-297. [CrossRef]

57. Windmeijer, F. A finite sample correction for the variance of linear two-step GMM estimators. J. Econom. 2005, 126, 25-51. [CrossRef]

58. Mesjasz-Lech, A. Logistics performance of European Union markets: Towards the development of entrepreneurship in the transport and storage sector. Glob. J. Environ. Sci. Manag. 2019, 5, 122-130.

59. Domański, C.; Pruska, K. Nieklasyczne Metody Statystyczne; PWE: Warszawa, Poland, 2000.

60. Levin, A.; Lin, C.-F.; Chu, C.-S. Unit root tests in panel data: Asymptotic and finite-sample properties. J. Econom. 2002, 108, 1-24. [CrossRef]

61. Im, K.S.; Pesaran, M.H.; Shin, Y. Testing for unit roots in heterogeneous panels. J. Econom. 2003, 115, 53-74. [CrossRef]

62. Pesaran, H. A simple unit root test in the presence of cross-section dependence. J. Appl. Econom. 2007, 22, 265-312. [CrossRef]

63. Blundell, R.; Bond, S. Initial conditions and moment restrictions in dynamic panel data models. J. Econom. 1998, 87, 115-143. [CrossRef]

64. Cottrell, A.; Lucchetti, R.J. Gretl User's Giude. Gnu Regression, Econometrics and Time-series Library. March 2021. Available online: http:/ / ricardo.ecn.wfu.edu/pub/gretl/manual/PDF/gretl-guide-a4.pdf (accessed on 9 February 2021).

65. Zużycie Paliw i Nośników Energii w 2019 Roku. Available online: https://stat.gov.pl/obszary-tematyczne/srodowisko-energia/ energia/ zuzycie-paliw-i-nosnikow-energii-w-2019-roku,6,14.html (accessed on 9 February 2021).

66. Basakha, M.; Kamal, S.H.M. Industrial development and social welfare: A case study of Iran. Socio Econ. Plan. Sci. 2019, 68, 100661. [CrossRef]

67. Zhang, W.; He, L.; Yuan, H. Enterprises' decisions on adopting low-carbon technology by considering the consumer perception disparity. Technovation 2021, 102238. [CrossRef]

68. Severo, E.A.; De Guimarães, J.C.F.; Dellarmelin, M.L. Impact of the COVID-19 pandemic on environmental awareness, sustainable consumption and social responsibility: Evidence from generations in Brazil and Portugal. J. Clean. Prod. 2021, 286, 124947. [CrossRef]

69. He, C.; Yang, L.; Cai, B.; Ruan, Q.; Hong, S.; Wang, Z. Impacts of the COVID-19 event on the NOx emissions of key polluting enterprises in China. Appl. Energy 2021, 281, 116042. [CrossRef]

70. Li, L.; Li, Q.; Huang, L.; Wang, Q.; Zhu, A.; Xu, J.; Liu, Z.; Li, H.; Shi, L.; Li, R.; et al. Air quality changes during the COVID-19 lockdown over the Yangtze River Delta Region: An insight into the impact of human activity pattern changes on air pollution variation. Sci. Total Environ. 2020, 732, 139282. [CrossRef]

71. Wang, S.; Zhang, Y.; Ma, J.; Zhu, S.; Shen, J.; Wang, P.; Zhang, H. Responses of decline in air pollution and recovery associated with COVID-19 lockdown in the Pearl River Delta. Sci. Total Environ. 2021, 756, 143868. [CrossRef]

72. Yang, Y.; Zhao, L.; Xie, Y.; Wang, C.; Xue, J. China's COVID-19 lockdown challenges the ultralow emission policy. Atmos. Pollut. Res. 2021, 12, 395-403. [CrossRef]

73. Aktar, M.A.; Alam, M.M.; Al-Amin, A.Q. Global economic crisis, energy use, $\mathrm{CO}_{2}$ emissions, and policy roadmap amid COVID-19. Sustain. Prod. Consum. 2021, 26, 770-781. [CrossRef]

74. Dai, R.; Feng, H.; Hu, J.; Jin, Q.; Li, H.; Wang, R.; Wang, R.; Xu, L.; Zhang, X. The impact of COVID-19 on small and medium-sized enterprises (SMEs): Evidence from two-wave phone surveys in China. China Econ. Rev. 2021, 67, 101607. [CrossRef]

75. Shafi, M.; Liu, J.; Ren, W. Impact of COVID-19 pandemic on micro, small, and medium-sized Enterprises operating in Pakistan. Res. Glob. 2020, 2, 100018. [CrossRef]

76. Jiang, P.; Van Fan, Y.; Klemeš, J.J. Impacts of COVID-19 on energy demand and consumption: Challenges, lessons and emerging opportunities. Appl. Energy 2021, 285, 116441. [CrossRef]

77. Prol, J.L.; Sungmin, O. Impact of COVID-19 Measures on Short-Term Electricity Consumption in the Most Affected EU Countries and USA States. iScience 2020, 23, 101639. [CrossRef] 